\section{A PINTURA DE HISTÓRIA NO BRASIL DO SÉCULO XIX: PANORAMA INTRODUTÓRIO}

\author{
Maraliz de Castro Vieira Christo \\ Prof. ${ }^{a}$ de História da Arte da Universidade Federal \\ de Juiz de Fora, Brasil \\ Doutora em História pela Universidade Estadual \\ de Campinas, Brasil \\ Bolsista da Fondation Getty junto ao Institut National \\ d'Histoire de l'Art de Paris (2003-2004)
}

Rua Melo Franco, 155, Juiz de Fora/MG, 36026-000, Brasil maraliz@acessa.com

RESUMEN: Acompañando la cronología política de Brasil en el siglo XIX, cuando pasa de Colonia y Reino Unido, a Imperio y República, se construyó rápidamente un panorama de la pintura de historia brasileña. No se destacó apenas la relación establecida con el poder, que pertenece a la génesis de ese género de pintura, pero sí sobresalió la actuación de artistas que muchas veces impusieron visiones propias del pasado, ante un medio intelectual aún incipiente. Se buscó verificar el proceso de construcción de la memoria y del olvido, peculiar a la pintura de historia. El miedo a la fragmentación, ocurrido en América Latina, con el descalabro del dominio español, llevó al Brasil a producir una iconografía que mostrase continuidad entre pasado y presente, como también la unidad, construida en la defensa de su territorio, respecto del enemigo externo. Fueron silenciadas en ese imaginario la esclavitud y las revoluciones internas, que solamente serán representadas en la República, vinculadas a la construcción de iconografias locales, necesarias al espiritu federativo.

PALABRAS CLAVE: Pintura de Historia en Brasil; Iconografía brasileña; Historia del Arte en Brasil.

\section{PAINTING OF HISTORY IN BRAZIL OF THE NINETEENTH CENTURY: INTRODUCTORY PANORAMA}

ABSTRACT: A rapid overview of Brazilian painting accompanied the political chronology of Brazil in the nineteenth century when the country passed from colony and United Kingdom to Empire to Republic. Not only did artists' relationships with power explain this kind of

\section{PINTURA DE HISTORIA EN BRASIL EN EL SIGLO XIX: PANORAMA INTRODUCTORIO}

RESUMO: Acompanhando a cronologia política do Brasil no século XIX, quando passa de Colônia e Reino Unido, a Império e República, construiu-se um rápido panorama da pintura de história brasileira. Não apenas destacou-se a relação estabelecida com o poder, que pertence à gênese desse gênero de pintura, mas, principalmente, apontou-se a atuação de artistas que muitas vezes impuseram visões próprias do passado, ante um meio intelectual ainda incipiente. Buscou-se verificar o processo de construção da memória e do esquecimento, peculiar à pintura de história. 0 medo à fragmentação, ocorrido na América Latina, com o esfacelamento do domínio espanhol, levou o Brasil a produzir uma iconografia que salientasse a continuidade entre passado e presente, como também a unidade, construída na defesa de seu território face ao inimigo externo; silenciando-se sobre a escravidão e as revoltas internas, que somente serão representadas na República, quando da construção de iconografias locais, necessárias ao espírito federativo.

PALAVRAS-CHAVE: Pintura de História no Brasil; Iconografia brasileira; História da Arte no Brasil.

painting but also their desire to impose their own visions of the past in this incipient intellectual milieu. This became part of a process of constructing memory and forgetfulness peculiar to historical paintings. Fears concerning fragmentation occurring in Latin America with the collapse of Spanish control led Brazil to produce an iconography that emphasized the continuity between past and present as well as its own unity in defense of an external enemy; silence regarding slavery and internal revolts which would not be represented until the Republic and then in the context of local iconographies in keeping with the federative spirit.

KEY WORDS: Painting of History in Brazil; Brazilian Iconography; History of the Art in Brazil. 
0 presente panorama baseou-se na recente e ainda escassa bibliografia sobre o tema, nos catálogos das Exposições Gerais de Belas Artes, como também no banco de dados relativo à pintura de história no Brasil, que estamos iniciando. Quando possivel, foram estabelecidos elos comparativos com a pintura internacional, visando perceber analogias e especificidades.

Apesar de incipiente e limitado pelo espaço de um artigo, o panorama aponta para a relação complexa entre artista e poder. Embora dependentes das encomendas e aquisições estatais, artistas altamente qualificados, buscando também prestígio internacional, encontraram oportunidades para expressar visões pessoais sobre o passado.

\section{Período colonial}

A pintura de história inexistia na América portuguesa, dedicando-se os pintores exclusivamente à decoração sacra e aos retratos. Entretanto, temas ligados à história profana podem ser encontrados em obras devocionais.

A invasão holandesa ao nordeste brasileiro, entre 1630 e 1654, durante a União Ibérica (1580-1640), marcou profundamente as regiões ocupadas. Tal experiência foi registrada de formas diferentes pelas forças envolvidas. Os pintores de Maurício de Nassau', particularmente o pintor oficial do governo holandês das Índias Ocidentais, Frans Post (1612-80), apresentam o sucesso da administração holandesa inserindo a topografia, a vida militar e as atividades econômicas em telas profundamente harmoniosas, constituindo-se nas primeiras paisagens pintadas por europeus no Novo Mundo. Os confrontos bélicos são lembrados apenas pelas ruinas ou fortificações presentes como detalhes no amplo espaço da paisagem. A tela Paisagem de Porto Calvo (uma das quatro obras de Frans Post oferecidas por Maurício de Nassau a Louis XIV em 1678-1679, hoje pertencente ao Museu do Louvre), por exemplo, evoca a batalha dos holandeses contra os portugueses, ao figurar, no fundo do quadro, dominando a paisagem, a fortaleza portuguesa de Bom Sucesso do Porto Calvo, em Alagoas, conquistada pelos holandeses em 1637 (Belluzzo, 1994).

0 espanhol Juan Bautista Mayno (ca.1578-1649) representou a reconquista, em 1625, do porto da Bahia de
Todos os Santos, em Salvador, em poder dos holandeses desde maio de 1624, pelas forças de Filipe IV (Filipe III de Portugal), comandadas por Don Fadrique de Toledo. A tela A recuperação da Bahía (1634), encomendada para o Salão dos Reinos do Palácio do Bom Retiro em Madrid, formava, com mais onze telas, dentre elas o famoso quadro de Velázquez A rendição de Breda (1634-5), um conjunto comemorativo de importantes vitórias militares do reinado de Felipe IV, considerado o primeiro conjunto de pintura de história realizado na Espanha (Pérez Vejo, 219, 250-51; Brown, 2000, 121-124).

Curiosamente, no século XVIII, retoma-se o tema das lutas pela expulsão dos holandeses. Trata-se, agora, de painéis realizados como obras sacras, em agradecimento à proteção divina.

Após a expulsão dos holandeses, em 1654, atribuiu-se à intervenção de Nossa Senhora dos Prazeres as vitórias das forças luso-brasileiras, vistas como técnica e numéricamente inferiores aos inimigos. Em gratidão, o Mestre de Campo General de Estado do Brasil e Governador de Pernambuco Francisco Barreto de Menezes mandou erguer, em 1656, no local onde se travaram dois decisivos combates $^{2}$, um santuário, denominado a Igreja de Nossa Senhora dos Prazeres dos Montes Guararapes. Ao longo do século XVIII, sete painéis votivos foram pintados ${ }^{3}$, dedicados a Virgem dos Prazeres, retratando as duas batalhas dos Montes Guararapes4.

Em estilo muito próximo, os painéis votivos representam singela e minuciosamente os combates, identificando por números os principais personagens, assim como a disposição dos terços e brigadas de infantaria envolvidos. Evidenciam a ação de brancos, índios e negros, organizados em grupos diferenciados, nas tropas luso-brasileiras, salientando a violência do confronto, exibindo cadáveres, mutilações e armas perfurando corpos. Quanto maior o perigo, maior o significado da intervenção de Nossa Senhora dos Prazeres.

A aproximação de registros tão diversificados permite pensar sobre sua complexidade e função. Os holandeses recorrem à tradição da pintura de paisagem, para demonstrar o poder ordenador da Companhia das Índias Ocidentais sobre os trópicos; os espanhóis inserem a colônia portuguesa e a momentânea supremacia sobre os holandeses na afirmação dos êxitos militares de Felipe IV, no bojo da lógica 
da pintura de história; por sua vez, os lusos-brasileiros dedicam e explicam suas vitórias à ação da providência divina ${ }^{5}$.

\section{ReIno Unido}

Na América portuguesa o ensino artístico limitava-se ao contato direto mestre-aprendiz. Apenas em 1800 deu-se a primeira experiência de ensino sistematizado com a criação da Aula Régia de Desenho e Figura, dirigida pelo pintor Manuel Dias de Oliveira (1764-1837), artista brasileiro que estudou em Portugal e foi pensionista na Academia Portuguesa de Roma. 0 método de ensino próximo ao classicismo romano, o abandono de temas religiosos em favor dos temas clássicos, alegóricos, históricos e paisagísticos, criavam a possibilidade de mudanças antes mesmo da chegada da Missão Artística Francesa (Fernandes, 2001, 43). Entretanto, é difícil avaliar o desdobramento dessa experiência, atropelada, de fato, pelos acontecimentos do novo século.

A nação brasileira surgirá em 1822, através de sua declaração de Independência. Apesar de algumas resistências, a transição entre o estatuto colonial e a constituição do estado nacional brasileiro pautou-se por certa estabilidade, comparada às revoltas que se estenderam pela América Latina e a fragmentaram. Indiscutivelmente, a vinda da família real portuguesa para o Brasil, em 1808, fugindo à invasão francesa na península lbérica, foi fator determinante para que esse processo se pautasse mais por continuidades que por rupturas. Após a transplantação do Estado Português para a colônia, D. João, então príncipe regente, em 1815, elevou o Brasil à categoria de Reino Unido ao de Portugal e Algarves, permanecendo na antiga colônia, mesmo após à queda de Napoleão Bonaparte, evitando possíveis movimentos de emancipação política.

Na França, a restauração dos Bourbon levará artistas muito próximos à extinta corte de Napoleão a buscarem o exílio ${ }^{6}$. Joachim Lebreton (?-1798), então secretário perpétuo da Quarta Classe de Belas Artes do Institut de France, também não resistirá às mudanças políticas. Como conservador do Louvre, Lebreton defendeu a permanência dos objetos artísticos conquistados pela França durante as guerras napoleônicas, contrariando os ingleses que exigiam sua devolução aos países de origem; por conseguinte, será excluido do cargo de secretário perpétuo e, posteriormente, do próprio instituto. Antes mesmo de sua expulsão do Institut de France, Lebreton iniciará gestões junto ao Ministro português Francisco José Maria de Brito, em Paris, para a implantação, no novo reino português na América, de um projeto de desenvolvimento da indústria e das artes, a exemplo do que aconteceu no México․

Os esforços de Lebreton, após amplas negociações, permitirá a vinda ao Brasil de um grupo de artistas franceses, conhecido pela historiografia como Missão Artística Francesa. Comporiam esse grupo artistas e artífices, destacando-se entre os primeiros: Nicolas-Antoine Taunay (1755-1830), pintor de paisagem, Jean-Baptiste Debret (1768-1848), pintor de história, e o arquiteto Grandjean de Montigny (1776-1850).

Jean-Baptiste Debret obteve sólida formação artística em Paris. Primo dos pintores François Boucher (1703-1770) e Jacques-Louis David (1748-1825), adolescente freqüentara o atelier de David, com quem viajou à Itália. Ingressou na Academia Real de Pintura e Escultura da França, em 1785, e, após, dedicou-se ao ensino de desenho, à pintura histórica neoclássica, com ênfase nas virtudes cívicas, como também em trabalhos decorativos para edifícios públicos e residências particulares. Em 1806, passa a pintar temas relativos às conquistas e glórias napoleônicas, expondo, no Salon, a tela Napoleão homenageia a coragem infeliz ${ }^{8}$, pela qual recebeu o Prix Décennal, instituído por Napoleão para recompensar artistas de mérito. Até 1814, Debret atendeu a várias encomendas de Vivant-Denon, diretor dos Museus durante os períodos do Consulado e do Império, que, sob a autoridade direta de Bonaparte, definia temas, escolhia artistas e fixava preços. Em 1815, tanto a carreira de Debret se desarticula com a queda de Napoleão, quanto sua vida pessoal se desmorona com a morte do único filho e a separação da esposa. Nada mais prendia Debret à França. Entre a possibilidade de trabalhar na Rússia, a convite do czar Alexandre I, e a proposta de Lebreton de vir para o Brasil, Debret escolhe os trópicos (Lima, 2004).

Caberá aos artistas franceses a organização do ensino artístico no Brasil e trabalhos próprios a seu métier: a cenografia das festas públicas, a documentação visual dos importantes momentos da corte, os retratos oficiais... A presença da família real no Rio de Janeiro, a abertura dos portos às nações amigas e a transformação da colônia 
em Reino Unido impuseram novos padrões de consumo artístico.

Ao chegar ao Brasil em 26 de março de 1816, Debret deparou-se com o luto oficial pela morte da rainha D. Maria I, ocorrida seis dias antes. Ainda nesse mesmo ano, pintou o Embarque na Praia Grande das Tropas Destinadas a Montevidéu ${ }^{9}$, marcando o início da intervenção portuguesa na região do atual Uruguai, estratégia de D. João para se sobressair no continente, face à desagregação do domínio espanhol.

A partir de então, Debret irá documentar a vida da corte em pequenos óleos, aquarelas e desenhos, destinados mais à circulação como gravuras do que à fixação em grande formato ${ }^{10}$.

Visando estabelecer alianças políticas européias, D. João promove o casamento do filho, D. Pedro, com a Arquiduquesa austríaca, D. Leopoldina, estreitando laços com Francisco I da Áustria, num momento em que a Santa Aliança ostentava grande poder ante o desmontar do império napoleônico. Para a chegada de D. Leopoldina, no Rio de Janeiro, em 12 de novembro de 1817, decorou-se ricamente a cidade e promoveu-se grandes festas, deixando-se apenas para as salas reservadas os debates sobre os levantes que ocorriam no nordeste, conhecidos como a Revolução de Pernambuco. Desde 1808, o Rio de Janeiro foi palco de muitas festas civis e religiosas, integrando o povo aos eventos da corte, além de criar a imagem de sua adesão aos fatos comemorados. Aos aniversários de D. João e D. Pedro, por exemplo, seguiase sempre a divulgação de atos do governo ou fundação de instituições, enriquecendo-se a imagem pública da corte. Debret mostra o desembarque da Arquiduquesa austríaca por dois ângulos: num desenho, posteriormente gravado", permite a visão panorâmica do acontecimento, destacando o caráter festivo, e, em pequeno óleo ${ }^{12}$, o encontro de D. Pedro com D. Leopoldina; fato que representava a união entre a casa de Bragança e de Habsburgo.

Em 6 de fevereiro de 1818, no dia em que se comemorava as Chagas de Cristo, unindo religião e política, D. João foi aclamado Rei. Debret, didaticamente, desenhou uma visão ampliada do povo nas ruas, destacando em primeiro plano a massa saudando o novo monarca, presente na sacada da grande galeria, especialmente construída para o evento ${ }^{13}$; como também uma cena do rei já aclamado no trono. Ainda durante as festividades, promoveu-se um bailado no teatro da corte, para o qual Debret produziu o pano de boca, aliando os personagens portugueses aos deuses da mitologia clássica ${ }^{14}$. Na construção das imagens, reafirmará o vinculo do novo reinado à cultura européia. Ao pintar, no mesmo período, o retrato do rei D. João $\mathrm{VI}^{15}$, Debret retomará o modelo tradicional, criado por Rigaud (1659-1743) para Louis XIV' ${ }^{16}$, em 1701, seguido por tantos outros pintores, a exemplo de Antoine-François Callet (1741-1823) ao retratar Louis ${ }^{17}$, em 1770 (Dias, 2006, 243-262). Embora permanecesse em pequeno formato, 0 retrato de D. João VI será gravado em Paris por Charles Pradier e amplamente divulgado.

Acompanhando a vida na corte de D. João VI, Debret desenhará, em 1819, o cortejo do batismo da princesa real D. Maria da Glória, no Rio de Janeiro; primeira filha de D. Pedro e de D. Leopoldina, que viria a ser D. Maria II, de Portugal. Além desse, outros dois desenhos serão realizados pelo pintor francês alusivos a dois momentos decisivos para a história do Brasil e de Portugal: a aceitação provisória da constituição de Lisboa, quando o príncipe D. Pedro, da varanda do teatro real, no Rio de Janeiro, jura, em nome do Rei, obedecer à constituição portuguesa, "tal como fosse sancionada pelas Cortes de Lisboa", e a partida da Rainha, D. Carlota Joaquina, ao tomar o navio real, destinado a conduzir a corte de volta a Portugal ${ }^{18}$.

A Revolução Liberal de 1820, na cidade do Porto, reivindicava a soberania portuguesa frente ao Brasil e exigia a volta de D. João VI, aceitando e jurando a nova constituição portuguesa. 0 juramento proferido por D. Pedro, em nome do pai, fora, no mesmo dia, repetido pelo próprio Rei, igualmente perante os súditos; entretanto, Debret preferiu eternizar o gesto do príncipe, ato correspondente à primeira atuação de D. Pedro na cena política.

Ao retornar a Lisboa, em 21 de abril de 1821, D. João VI deixou o filho no poder, visando à continuidade da casa de Bragança no Brasil, cuja independência era previsivel.

\section{Primeiro Reinado}

Pressionados pela atuação das Juntas Governativas de Lisboa, que exigiam o retorno de D. Pedro a Portugal e a volta 
do Brasil à condição de colônia, como também pelo clima de descontentamento, que poderia fragmentar a unidade territorial, os políticos liberais reconheceram no príncipe-regente um instrumento eficaz para a independência. Assim, em 12 de outubro de 1822, D. Pedro fora aclamado Imperador do Brasil. Debret representará o momento da aclamação de D. Pedro, no Campo de Santana, mostrando, como num friso, no alto da sacada, D. Pedro ao lado da família e dos políticos, que incitam a população, comprimida na praça, a dar vivas ao imperador constitucional ${ }^{19}$.

Vivenciando diretamente a efervescência política do período, Debret dedica-se, a partir de indicações de D. Pedro, à confecção dos novos símbolos nacionais (bandeira, comendas, uniformes...), e às festividades para a coroação do novo imperador.

Ao contrário das representações anteriores, o desenho da coroação dera origem a uma tela de grande formato ${ }^{20}$. Nela, há nítida preocupação em diferenciar-se simbolicamente D. Pedro I, imperador do Brasil, do pai, D. João VI, rei de Portugal. Desde o desaparecimento de D. Sebastião em terras africanas, os reis portugueses não cingem a coroa, mantendo-a apenas ao lado do trono, sobre uma almofada vermelha. Debret representa o imperador brasileiro sentado no trono, em posição elevada, coroado, tendo à frente o presidente do Senado da Câmara Municipal do Rio de Janeiro, Lúcio Soares Teixeira de Gouveia, ajoelhado, jurando-Ihe fidelidade em nome do povo, no interior de uma igreja barroca, lotada. 0 sentido religioso da cena é evidente, assemelhando-se o imperador a um santo, no altar. A matriz iconográfica da cena encontra-se na coroação de Napoleão Bonaparte, de David ${ }^{21}$. A exemplo de Napoleão, D. Pedro I pretendia ser reconhecido como senhor de seu destino. Para fortalecer-lhe a imagem de impetuoso e aventureiro, exigia ser representado, sempre, calçando botas.

Para as festividades, Debret, como cenógrafo da corte, executara um novo pano de boca destinado ao teatro real. Através dele, o artista reforçará a idéia da monarquia constitucional, da riqueza da terra, da união das três raças (índios, negros e brancos) na defesa do império, bem como a vinculação do novo país à civilização européia. Vinculação mais evidenciada quando José Bonifácio de Andrada e Silva, político influente no processo de independência, solicitou ao artista substituir algumas palmeiras por ele- mentos arquiteturais clássicos; levando Debret a introduzir cariátides na cena.

A harmonia e união expressas no pano de boca não se concretizaram no reinado de D. Pedro I. A princípio, o Imperador neutralizara a resistência portuguesa, no nordeste, à independência do Brasil; depois, desgastou-se com os partidos ao rejeitar a constituição votada, outorgando ao país uma outra, de sua autoria; enfrentou sucessivas revoltas; perdeu a Província Cisplatina, que se constituiu na República Oriental do Uruguai; por fim, abdica ao trono em favor do filho, retornando a Portugal, em 13 de abril de 1831.

0 príncipe e herdeiro do trono, D. Pedro de Alcântara, com 5 anos, fora levado ao palácio e aclamado, na sacada, novo imperador. Será essa a terceira aclamação representada por Debret durante seus 15 anos de Brasil. Ao contrário das anteriores, o pintor não representará aqueles que aclamam como massa indistinta. Na cena, percebe-se, junto ao palácio, homens a cavalo, portando bandeiras, com vivas ao imperador; em seguida, a guarda, circundando o prédio; atrás dela, alguns populares. Mais do que um ambiente festivo, o desenho revela a tensão vivida pelo país.

Nessa conjuntura, Debret opta por retornar à França, onde publicará a Viagem Pitoresca e Histórica ao Brasip2. Tal obra se insere na vasta produção da literatura de viagem, caracterizada, já a partir do século XVIII, por uma reflexão dos viajantes sobre a sua própria sociedade de origem e o momento histórico vivido, bem como quanto às teorias de conhecimento da espécie humana e as possibilidades de integração das novas regiões ao mapa da evolução do homem.

Debret produzira no Brasil não apenas obras referentes aos acontecimentos da corte, como também muitos desenhos e aquarelas sobre hábitos e costumes brasileiros, guiado pelo olhar de pintor de história, como ele mesmo afirmara (Debret, 1989, 23-24); em Paris, organiza-os em três volumes, acompanhados de textos explicativos. 0 artista objetivava construir uma "biografia nacional" do Brasil, demonstrando como, apesar dos problemas herdados do período colonial, o novo país encontrava-se a caminho da civilização; apontando a importância da miscigenação racial e da educação para o êxito desse processo. 0 pitoresco de Debret não reside na descrição da fauna e da flora 
brasileiras, a contrário senso, o artista enfatiza o espaço urbano, contrapondo-o à idéia de um Brasil selvagem e exótico.

Em 1834, Debret publicou o primeiro volume, concentrando desenhos sobre indígenas e as relações com o homem branco, buscando demonstrar como os índios eram capazes de evoluir de seu estágio natural, incluindo-se na sociedade brasileira. 0 pintor não idealiza o índio, tampouco 0 transforma em símbolo nacional. Debret retoma a imagem do indígena como habitante natural, visando estabelecer uma origem da qual partiria o processo de civilização do pais.

0 artista destinara o segundo volume, publicado no ano seguinte, às atividades econômicas, salientando a dependência relativa à mão-de-obra escrava, parcela significativa da população brasileira. Dedicados geralmente ao trabalho, negros e negras exibem vitalidade física, necessária ao surgimento, pela miscigenação, de um povo resistente aos extremos de um pais tropical. Embora represente, em alguns poucos desenhos, castigos corporais a que eram submetidos os escravos -acarretando protestos do Instituto Histórico Geográfico Brasileiro-, Debret não se pauta por uma posição abolicionista.

0 terceiro e último volume será publicado em 1839, dedicado às instituições políticas e religiosas. Apesar da crítica às superstições e à ineficiência administrativa, Debret se mostra confiante no presente e, principalmente, no futuro. As últimas litografias desse volume resultam do trabaIho, produzido como pintor oficial da Corte. As imagens, originalmente concebidas para uma definição simbólica da nação, finalizam o discurso do artista, marcado pelo otimismo quanto ao papel histórico da Casa de Bragança no processo civilizatório brasileiro, apesar dos erros cometidos.

A Viagem Pitoresca e Histórica ao Brasil é constantemente utilizada pelos historiadores brasileiros como fonte iconográfica pertinente ao estudo dos mais variados temas. Com raras exceções, as gravuras são tomadas como documentos visuais, sem subordinação à sua natureza específica. Quando muito realiza-se a operação contrária, valorizando-a como documento, não de uma realidade, mas de um olhar estrangeiro, indefinido e homogeneizado. A produção de Debret, a exemplo de outros "artistas viajantes" do período, é classificada como iconografia, não vinculada à tradição da pintura de história, de paisagem ou de cenas de gênero. Sua condição de artista também não é levada em consideração, eclipsada pela de viajante. A obra criada não é vista como construção artística, mas registro de testemunha ocular. A utilização do conceito de "artista viajante" coloca na fronteira da história da arte significativa produção artística do século XIX, desenvolvida em solo não europeu (Mattos, 2007).

\section{Segundo Reinado}

Após a aclamação do menino-rei, D. Pedro de Alcântara, seguiram-se nove anos em cujo decurso regentes exerceram o poder, em meio a clima conturbado por rebeliões em vários pontos do país e ásperos debates, opondo centralização e descentralização político-administrativa. Constituiu a antecipação da maioridade do futuro imperador, de 18 para 14 anos, a solução encontrada pelos liberais, dando início a longo reinado.

A coroação, em 18 de julho de 1841, fora representada por dois quadros de modelos iconográficos diferentes, reveladores de relativa complexidade dos meios artísticos da corte. 0 artista francês, ex-aluno de Antoine-Jean Gros (1771-1835), François-René Moreau ${ }^{23}$ (1807-1860), que teria chegado ao Brasil no final da década de 30 e se fixado no Rio de Janeiro em 1841, representa, nesse mesmo ano, D. Pedro de Alcântara, de genuflexo, recebendo a coroa do primaz do Brasil, D. Romualdo Antônio de Seixas, na pequena capela imperial ${ }^{24}$. A tela retoma a tradição medieval do poder real conferido por Deus, assemelhando-se às representações da coroação de Carlos Magno, por Leão III, em Roma ${ }^{25}$. Igualmente em 1841, Manuel de Araújo Porto Alegre (1806-1879), brasileiro, discípulo de Debret, tendo-o seguido no retorno à França e estudado também no atelier de Gros, iniciara um quadro ${ }^{26}$ de aproximadamente $40 \mathrm{~m}^{2}$, representando não a cerimônia íntima da sagração e coroação, mas D. Pedro II, já coroado, com a estatura adulta, portando todos os símbolos majestáticos; apresentando-se aos súditos no interior de suntuosa construção, montada pelo próprio pintor-arquiteto, unicamente para as festividades (Squeff, 2007). Entre as 160 figuras que compõem a cena, o artista reuniu membros da Igreja, Corte e políticos, numa rica simbologia da monarquia brasileira. 
Na tela, um detalhe de primeiro plano é significativo: a constituição e o missal sobre pequena mesa, lembrando que a sagração divina precisaria ser referendada pelo pacto com os cidadãos. Embora a tela de Porto Alegre seja tributária à composição apresentada por François Gérard (1770-1837) para a Sagração de Charles X em Reims ${ }^{27}$, onde uma diagonal une o rei aos súditos, estranhamente, nela, o imperador brasileiro e seus súditos não se olham; as articulações do poder acontecem à sua revelia. Apesar de muito próximo ao grupo de maior influência sobre $D$. Pedro II, Porto Alegre teve a tela preterida em relação ao quadro de François-René Moreau, apresentado na Exposição Geral de 1842 e adquirido pelo imperador, que o colocara na sala do trono, condecorando o artista com o Hábito da Ordem de Cristo. Provavelmente, tal fato levou Porto Alegre a abandonar a obra, que restou inacabada.

François-René Moreau realizou outro quadro para D. Pedro II, em 1844, Proclamação da Independência ${ }^{28}$, ocorrida em 1822. Inicia-se assim a organização de uma memória nacional, a partir de um marco fundador, criando-se um mito de origem. No quadro, D. Pedro I aparece a cavalo em meio ao povo festivo, acenando com o chapéu. Ao mesmo tempo que enfatiza a popularidade de D. Pedro I, François-René reafirma a legitimidade dos herdeiros da casa de Bragança ao trono brasileiro, por direito divino. No quadro, a maioria olha para o céu, como se o futuro imperador estivesse apenas consumando a vontade de Deus (Oliveira, 1999, p.90).

Em 1863, François-René Moreau pintou Dom Pedro I/ visitando os doentes de Cólera Morbus ${ }^{29}$, seguindo a mesma temática da obra de Gros, Bonaparte visitando os pestilentos de $\mathrm{Jaffa}^{30}$, de 1804 , sem, entretanto, a dramaticidade do segundo e bem mais sutil quanto aos poderes de cura de um imperador. A epidemia do cólera, que se propagou por várias partes do país na década de 50 , apenas foi registrada pela pintura, no Brasil, objetivando evidenciar a ação dos governantes ${ }^{31}$, diferentemente da pintura de Juan Manuel Blanes, Um episódio da febre amarela em Buenos Aires ${ }^{32}$, de 1871, que expõe a dor de uma família vitimada ${ }^{33}$.

Na segunda metade do século XIX, a pintura de história, no Brasil, é marcada pela produção da Academia Imperial das Belas Artes (AIBA). Apenas quando a estabilidade política foi alcançada, fundou-se a Academia, em 1826, cuja existência anterior baseara-se exclusivamente em decretos, que se sucediam ao sabor das transformações políticas, redundando na modificação do projeto original de Lebreton. Nos dez anos anteriores, os integrantes da Missão Artística Francesa ministraram aulas em ateliês, à maneira francesa, enquanto lutavam pela implantação da Academia. Em 1826, restavam apenas Grandjean de Montigny e Jean-Baptiste Debret (Lebreton morrera em 1819 e Nicolas-Antoine Taunay voltara a Paris em 1821). Mesmo após a fundação, a rivalidade entre artistas franceses e portugueses impedia o funcionamento pleno da academia; somente resolvido sob a gestão de Félix-Émile Taunay. Filho de Nicolas-Antoine Taunay, com quem viera para o Brasil, Félix administrou a academia entre 1834 e 1851, implantando um ensino próximo, no que era possível, ao modelo da École des Beux-Arts de Paris, instituindo, em 1845, o prêmio viagem ${ }^{34}$. Eram professores da academia muitos ex-alunos dos franceses, dentre eles Araújo Porto Alegre, que voltara de Paris em 1837.

A estabilidade política permite debates em torno da constituição de uma memória nacional, unindo Estado e instituições, principalmente o Instituto Histórico e Geográfico Brasileiro (IHGB), criado em 1838, e a Academia Imperial das Belas Artes. Uma visão apressada desse processo determinaria a priori os papéis de cada um: o imperador mandou, o Instituto escreveu, a Academia ilustrou. A complexidade da construção de uma memória nacional exige pesquisa constante sobre como se processa em cada situação concreta. Interessante perceber o caminho trilhado na tentativa de dotar o país de um passado único e coerente, como também os conflitos vivenciados no percurso.

Estudos sobre o IHGB apontam para a homogeneidade de sua militância intelectual, caracterizada pelo compromisso com o regime e a fidelidade ao Imperador. A continuidade entre passado, presente e futuro seria o fio condutor a tecer a memória nacional. 0 Estado brasileiro era visto como o legítimo herdeiro do império português: mantivera-se a mesma língua, o mesmo regime monárquico e a mesma origem dinástica. A independência, por conseguinte, seria processo natural, não traumático, ao contrário do ocorrido nos outros países da América Latina. Quanto às raizes da nacionalidade, alguns, a exemplo de Varnhagen, privilegiavam as origens européias, outros buscavam-na nos indígenas; prevalecendo, por fim, a visão romântica de viés indigenista (Guimarães, 1988). As poucas pesquisas existentes sobre a AIBA não permitem idéia tão clara de 
sua trajetória. Evidentemente as duas instituições trabaIharam muito próximas: alguns artistas foram membros do IHGB, dentre eles Félix-Émile Taunay e Araújo Porto Alegre, assim como a pintura de história exigia que os artistas utilizassem, em parte, métodos de trabalho do historiador e acompanhassem suas publicações.

Percebe-se, nas Exposições Gerais da década de 40, a presença de temas ligados ao passado colonial, enaltecedores da dedicação e altruísmo dos portugueses. Nesse aspecto, a pintura de história no Brasil difere sobremodo do observado no restante da América Latina, onde o período colonial é pouco representado, passando-se diretamente do tempo pré-hispânico, descobremento e conquista, às guerras de independência, como se fossem períodos consecutivos (Gutiérrez y Gutiérrez Viñuales, 2006).

Acompanhando-se as Exposições Gerais, em 1841, José Correia de Lima apresentou a tela Magnanimidade de Vieira $^{35}$, graças à qual recebeu o grau de Cavaleiro da Ordem de Cristo. No ano seguinte, Louis Auguste Moreau pintou, por encomenda de D. Pedro II, os retratos dos navegadores Pedro Álvares Cabral, Vasco da Gama e Afonso de Albuquerque, enquanto Rafael Mendes de Carvalho mostrou a tela Desembarque em Porto Seguro de dom Pedro Alvares Cabral e plantação da cruz pelos selvagens. $\mathrm{Na}$ Exposição de 1843, Manuel Joaquim de Melo Corte Real exibia o quadro Nóbrega e seus companheiros, que representava, no dizer de Porto Alegre, "a civilização cristã combatendo heroicamente a antropofagia" (Squeff, 2004, 220); enquanto João Maximiano Mafra apresentava um retrato de Gonzaga, na prisão ${ }^{36}$. Por fim, em 1848, José Correa de Lima expôs Dona Maria de Souza em Pernambuco, lembrando o sacrifício de uma mulher na luta contra os holandeses ${ }^{37}$.

Entretanto, caberá à geração seguinte, sobrelevando-se os pintores Victor Meirelles e Pedro Américo, a construção dos mais expressivos ícones da memória nacional brasileira.

Araújo Porto Alegre, como professor e diretor da AIBA (1854-1857), advogava que a arte brasileira deveria seguir estilos europeus, visando incluir-se no rol das nações civilizadas, porém, privilegiando temática que valorizasse a paisagem e os feitos históricos do Império (Squeff, 2004). Porto Alegre aconselhara o promissor pensionista Victor Meirelles, a pintar a Primeira missa no Brasilis ${ }^{38}$ fig.
1), tal como descrita, em 1500, pelo escrivão da frota de Pedro Álvares Cabral, Pero Vaz de Caminha, em carta ao rei de Portugal. Aliando estilo agradável e profunda capacidade de observação, a carta de Caminha tornava presente um passado distante, associando dois ancestrais legítimos para a nação: índios e portugueses. 0 escrivão, portanto, mostrava o encontro pacífico entre pagãos e católicos ${ }^{39}$.

Estando na Europa desde 1853, graças ao prêmio viagem da AIBA, depois de período em Roma, Victor Meirelles fixa-se em Paris, onde, em 1859, inicia a pintura do quadro. Nele, índios e portugueses, integrados por uma elipse, assistem harmoniosamente à missa celebrada num altar erguido em meio à paisagem tropical. 0 núcleo central, onde encontra-se o altar, fora inspirado na obra de Horace Vernet (1789-1863), a Primeira missa em Kabylie ${ }^{40}$, apresentada no Salon de 1855, em Paris. 0 artista francês pintara um episódio contemporâneo, ocorrido em 1853, integrante do projeto colonial francês na África do Norte, do qual fora testemunha ocular. Vernet era, sem dúvida, importante referência para um jovem pintor da América Latina, incumbido da missão de produzir o ícone fundador de sua nação. É necessário, entretanto, afirmar a diferença entre os dois quadros. Vernet procura o anedótico, o impacto da cena aproximada, dos detalhes fortes e pitorescos; seu cenário é agreste e a missa, uma pausa no confronto com os infiéis. Victor Meirelles tudo relaciona com extrema leveza; a conversão é possível e natural. 0 título do quadro de Meirelles é sintomático, refere-se não ao lugar específico do fato histórico, mas, à futura nação. Seus índios, embora estampem pinturas corporais, são idealizados, não identificados como pertencentes a nenhuma tribo específica. A natureza, própria ao nordeste brasileiro, subordina-se ao espírito suave do quadro. 0 tema "primeira missa" possui significativa iconografia no continente americano ${ }^{41}$; no Brasil, será retomado na República, como marco fundador da criação de cidades, enfatizando-se as histórias regionais ${ }^{42}$.

A Primeira missa no Brasil, de $9 \mathrm{~m}^{2}$, foi exposta no Salon de 1861. Meirelles será o primeiro artista brasileiro a participar da exposição parisiense, aumentando o poder de persuasão do quadro, quando de seu retorno ao Brasil. 0 espectador moderno se colocava, não diante de uma representação, mas impregnava-se da sensação de assistir à missa real. 


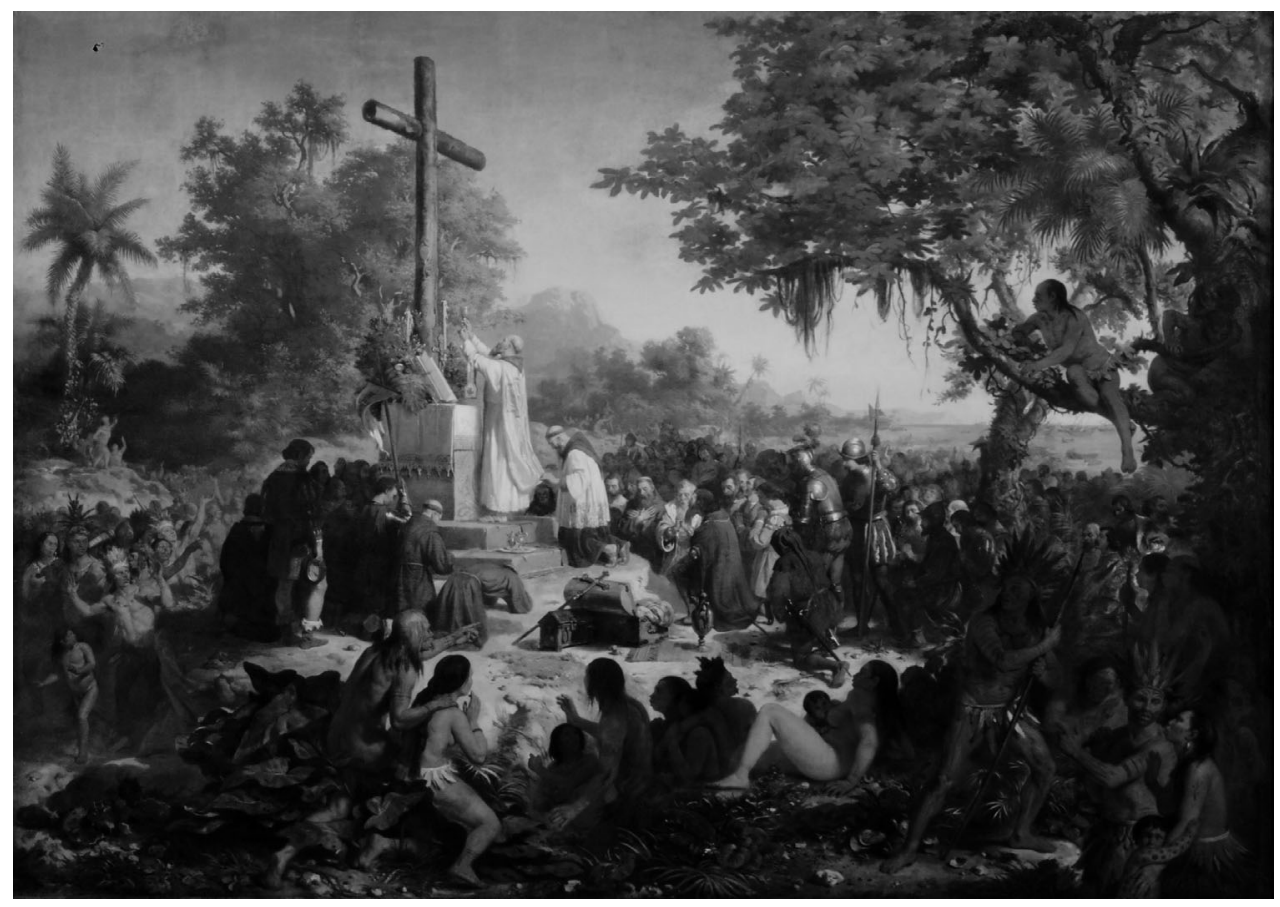

No cuidado de estabelecer continuidade entre presente e passado colonial, a luta contra os holandeses tornou-se um dos temas privilegiados pelo IHGB. A expulsão do invasor aproximou, por sua vez, as três raças (indio, branco e, agora, o negro), transformando-se em importante fator na construção da identidade nacional. A união das três raças conferindo sentido à nação brasileira passou a merecer a atenção do IHGB a partir da obra de von Martius, vencedora do concurso "Como se deve escrever a História do Brasil?" (Martius, 1845).

Victor Meirelles recebera, em 1872, a encomenda de uma grande tela sobre a primeira batalha dos Guararapes ${ }^{43}$. Dirigiu-se a Pernambuco, conheceu a região, procurou os antigos painéis votivos, pesquisou no Instituto Arqueológico Histórico e Geográfico Pernambucano e, principalmente, leu a obra de Varnhagen, História das lutas contra os Holandeses no Brasil, publicada um ano antes ${ }^{44}$. Meirelles compôs os personagens na cena a partir da narrativa de Varnhagen, evidenciando um combate entre heróis e não entre civilizados e bárbaros. As três raças são representadas pelo pintor dignamente, embora mantendo a hierar- quia entre elas, já preconizada por von Martius. Entretanto, o artista evita o exotismo racial na tela; a união das raças deve, em parte, anular as diferenças, deixando sobressair um novo homem, o brasileiro (Coli, 2005, 60).

Meirelles não representou a violência e o horror da guer$\mathrm{ra}$, preferindo mostrar em sua tela de $46 \mathrm{~m}^{2}$, o encontro feliz de heróis, como ele mesmo declarara. Seu quadro é estático; a composição, intelectual e espiritualizada; suas figuras se movem com lentidão. Antes de estudar em Paris, Meirelles freqüentou em Roma o atelier de Nicola Consini, discípulo de Tommaso Minardi; ali a formação neoclássica recebida na AIBA se apurou no contato com o purismo. Embora Araújo Porto Alegre tenha aconselhado Meirelles a estudar as obras de Gros, Delaroche e Vernet, a tela produzida em nada thes é devedora (Coli, 2005, 60).

Se, no início do Segundo Império, a produção da AIBA, no que tange à pintura de história, se fixara no passado colonial e na construção de mitos de origem, a Guerra do Paraguai imporá como premente a representação da história contemporânea. Também conhecida como Guerra 
da Tríplice Aliança (Brasil, Argentina e Uruguai, contra o Paraguai), o conflito durou de 1864 a 1870, deixando exaurido o Paraguai e acarretando a morte em combate de 150 a 300 mil soldados (Vainfas, 2002, 322). Ao lado da Invasão Holandesa, a Guerra do Paraguai tornou-se tema predominante nos debates historiográficos publicados pela Revista do Instituto Histórico e Geográfico Brasileiro ${ }^{45}$. A guerra era explicada como uma reação do império à agressão paraguaia, uma luta da civilização contra a barbárie representada pelo "tirano" Lopez. Mesmo antes do término do conflito, o imperador enviou para o front o napolitano Edoardo de Martino, como pintor oficial da Corte, para produzir imagens das vitórias brasileiras, executando, entre 1868 e 1872, onze telas referentes aos conflitos (Pereira, 1999, 150; Belluzzo, 1988).

Por sua vez, o Ministro da Marinha, Afonso Celso de Assis Figueiredo, encomendou a Victor Meirelles duas telas para o Museu da Marinha, criado com o Decreto 4116, de 14 de março de 1868 (Mello Jr., 1982, 81). Assim como Edouardo de Martino, Meirelles irá ao cenário das batalhas, mas produzirá algo a mais que registros descritivos. Suas pinturas, Combate Naval de Riachuelo ${ }^{46}$ e A Passagem de Humaitád7, são telas de grande formato, com propostas absolutamente opostas (Christo, 2007, 169-188).

Passagem de Humaitá não apresenta figuras humanas, os navios são quase imperceptíveis, a tela se resume a massas negras e vermelhas. Sob o pretexto de representar uma batalha noturna, o artista constrói quase uma abstração monocromática em mais de $11 \mathrm{~m}^{2}$. A natureza divergente de Passagem de Humaitá acentua-se se comparada ao Combate Naval de Riachuelo, de $37 \mathrm{~m}^{2}$. Nele, todos os elementos narrativos de uma batalha naval estão visíveis; distinguemse facilmente navios e destroços, vencedores e vencidos, heróis e anônimos. Sobre ele os jornalistas da época mais se detiveram; sua imagem, ao longo do tempo, foi a mais reproduzida e perpetua-se ainda hoje nos livros escolares. Quanto à Passagem de Humaitá, a tela continua imersa em grande silêncio ${ }^{48}$. Essa diferença aponta para a existência de uma geração de artistas mais autônoma, não apenas presa às exigências do poder, exigindo do historiador um olhar mais demorado sobre a complexidade de cada obra.

Para seus contemporâneos, Passagem de Humaitá era bela pintura, mas nunca de evento histórico. Os visitantes da exposição de 1872 não reconheceram no quadro a apre- sentação do tema presente no catálogo. 0 artista trocou o papel de narrador de um acontecimento, visto que 0 desempenhara plenamente no Combate naval de Riachuelo, pelo de espectador. Ao contrário da natureza límpida, contemplada pelo pintor alemão Friedrich - ao qual nossa memória sempre remete quando pensamos o artista como espectador do mundo -, Meirelles observa um indecifrável combate distante, que mal se distingue na escuridão. A procura do entendimento impossivel, numa perscrutação lenta e angustiante, fustiga o olhar; constrói uma delicada perspectiva cromática, que nada revela do heroismo ou da dor humana. 0 artista não mobiliza nossas paixões, nos aprisionando numa calma e terrivel sensação de impotência.

Também perturbadoras serão as representações de Pedro Americo de Figueiredo e Melo (1843-1905) relativas à Guerra do Paraguai.

Primeira pintura histórica realizada por Pedro Americo, a Batalha de Campo Grande ${ }^{49}$, de $17 \mathrm{~m}^{2}$, não foi fruto de encomenda, mas da ansiedade do jovem pintor, recémchegado de estudos na École des Beaux-Arts de Paris, em afirmar-se no cenário artístico nacional. A principio, o quadro submete-se às convenções de uma pintura histórica: apresenta um momento preciso da batalha e destaca um grupo principal, em torno do qual toda a ação deve se desenvolver. Não temos dificuldade em distinguir o comandante-em-chefe das forças brasileiras, montado num cavalo branco, ocupando o vértice de uma composição triangular; tampouco temos dúvidas sobre a superioridade do exército brasileiro face à barbárie do inimigo. Entretanto, dois aspectos chamam a atenção: o momento da batalha escolhido e a falta de energia apresentada pelo Conde D'Eu, comandante-em-chefe e príncipe consorte.

Pedro Americo escolhe a cena da última grande batalha da guerra, ocorrida em 16 de agosto de 1869, quando os paraguaios, após sofrerem perseguição, contra-atacam, colocando em perigo a vida do Conde d'Eu (Taunay, 1926, 198-199). 0 pintor representa o momento preciso em que um ajudante-de-ordens procura protegê-lo, segurando-Ihe as rédeas do cavalo; impedindo-o de prosseguir.

Por si só, a escolha do momento em que os ajudantes impedem o avanço do comandante não nos parece muito 
favorável à construção de uma imagem grandiloqüente para o conde, fato percebido e questionado por militares a quem Pedro Americo solicitou ajuda na reconstituição de detalhes da batalha, dentre eles Alfredo d' Escragnolle Taunay ${ }^{50}$. Entretanto, o que mais chama a atenção não é o rompimento da hierarquia (o fato de um comandado conter o ímpeto do comandante), mas a forma fragilizada e inexpressiva como este último é representado.

No segundo quadro relativo à Guerra do Paraguai, a BataIha de Avahy ${ }^{51}$ (fig. 2), Pedro Americo privilegia a tensão da luta em detrimento do herói. Trata-se de uma grande tela, aproximadamente $60 \mathrm{~m}^{2}$, de composição elíptica, onde a unidade de ação é abandonada para favorecer a percepção do caos da guerra. Múltiplos episódios paralelos se perdem, envoltos por grande redemoinho. 0 herói, Caxias, então comandante-em-chefe das forças aliadas, permanece isolado, em segundo plano, observando a cena à distância, como "turista", na perspicaz definição do poeta Manuel Bandeira (Bandeira, 1967, 553-555). 0 artista enfatiza a luta ensandecida em meio à fumaça, lama e sangue, como defendia o próprio Leonardo da Vinci, em prejuízo da clara compreensão do episódio. Para o historiador Jorge Coli, Pedro Americo retoma certos princípios essenciais da pintura de batalha do século XVII, dialogando com artistas como
Jacques Courtois (1621-1676), il Borgognone, que valorizavam o caos da luta e não o protagonista (Coli, 2002, 113-128). A Batalha do Avahy é mais que uma encomenda oficial, celebrativa de importante vitória, é uma crítica da própria guerra. A obra foi pintada e exposta em Florença, causando positivo impacto.

Victor Meirelles e Pedro Americo atualizaram o gênero de batalhas, já decadente após a queda de Napoleão Bonaparte. Sob seus pincéis, a guerra tornou-se épica. Na Exposição Geral de Belas Artes de 1872, foram apresentadas a Passagem de Humaitá, o Combate Naval de Riachuelo, assim como a Batalha do Campo Grande, atraindo grande público. Em 1876, as telas de Victor Meirelles foram enviadas pelo governo imperial para participar da Exposição de Filadélfia, comemorativa do centenário da emancipação norte-americana, contando com a presença de D. Pedro II (Mello Jr., 1982, 72). A Exposição Geral de Belas Artes de 1879, onde e quando foram exibidas lado a lado a Batalha dos Guararapes e a Batalha do Avahy, recebeu um número de visitantes nunca igualado no Brasil até hoje (Castro, 2007, 40-44). As telas foram alvo de grandes debates na imprensa, envolvendo mais de cem artigos enfatizadores das diferenças de concepção de pintura de história que ambas expressavam (Guarilha, 2005). De um lado,

2. Pedro Américo. Batalha de Avahy, 1872-1877. Óleo sobre lienzo, $600 \times 100 \mathrm{cms}$. Museu Nacional de Belas Artes, Rio de Janeiro/RJ.

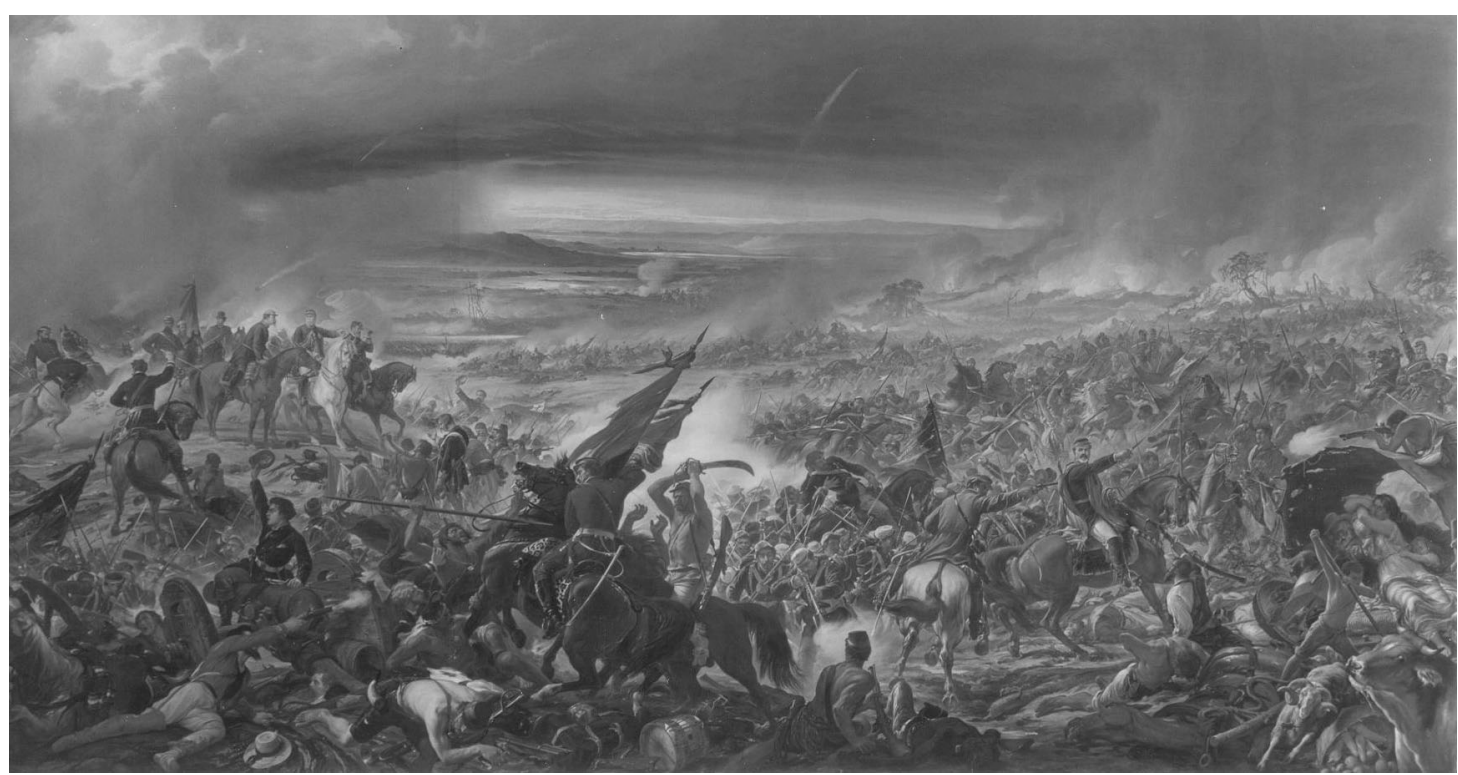


o encontro feliz de heróis no passado, a união das raças antevendo a pátria e a composição rigorosa, preservando a junção lógica do espaço, tempo e ação. De outro, o patriotismo paradoxalmente fundindo-se ao caos da história contemporânea.

Muitas outras foram as representações da Guerra do Paraguai ${ }^{52}$, mas, indiscutivelmente, nenhuma atingiu a qualidade pictórica e a repercussão das telas de Victor Meirelles e Pedro Americo. Tanto pela permanência do tema até o final do século XIX, quanto pela qualidade das principais obras produzidas, percebe-se a expressão do investimento do Estado imperial brasileiro e dos artistas, superando em muito a produção dos demais países da América Latina sobre o tema. Excetuando-se o quadro do uruguaio Juan Manuel Blanes, Paraguai: imagem de sua pátria desolada (c. 1879) ${ }^{53}$, as obras dos argentinos Cándido López e José Ignacio Garmendia, assim como do suíço Adolfo Methfessel, embora registros importantíssimos, distanciam-se das grandes "máquinas" da pintura de história ${ }^{54}$.

Paralelamente às representações da Guerra do Paraguai, questões ligadas à constituição do povo brasileiro persistem. No segundo império, o índio será tomado como símbolo nacional, principalmente na literatura romântica, em parte caudatária de Chateaubriand. 0 índio idealizado era normalmente o tupi ou o guarani, o macrotronco indígena vítima da colonização e da evangelização, já praticamente extinto ou diluído pela miscigenação no século XIX. 0 índio real, o botocudo, desde D. João VI vítima de campanhas de extermínio, era o vilão, o índio selvagem, estigmatizado. Embora tardiamente, a pintura também abordará temas ligados ao indianismo.

Ao contrário da experiência do México, a partir do período de Maximiliano, em que se identificava no passado préhispânico o berço da identidade mexicana, como também se enfatizava explicitamente a resistência nativa ao massacre promovido pelos colonizadores ${ }^{55}$, a pintura indianista brasileira não mostra o passado pré-cabralino, tampouco cenas de conflito. Para alguns historiadores, como Varnhagem, a História do Brasil começava com o descobrimento, em 1500, sendo o período anterior domínio da etnografia. Os personagens indígenas, emersos da ficção para as telas, eram, na maioria, mulheres apaixonadas que espelhavam, em seus dramas pessoais, a impossibilidade de sobrevivência dos valores indígenas face à cultura européia. Moema,
Marabá e Iracema demonstram como amar o branco é destruir-se a si próprio ${ }^{56}$.

0 último Tamoio ${ }^{57}$ (fig. 3), tela pintada por Rodolpho Amoêdo (1857-1947), quando de seus estudos em Paris, e exposta no Salon de 1883, é obra singular. Retrata o corpo do índio Aimberê devolvido à praia e amparado pelo padre Anchieta. 0 tema de pintura de Amoêdo integra o poema épico A confederação dos Tamoios, publicado em 1856, por Gonçalves de Magalhães, um dos responsáveis pela introdução do romantismo no Brasil. Aimberê era chefe dos Tamoios, nação indígena que combatera os portugueses no século XVI, aliando-se aos franceses, entre 1554 e 1567, quando estes invadiram a Baía da Guanabara. Representar o último tamoio é apontar o conflito do passado; entretanto, Rodolpho Amoêdo não radicaliza sua representação. 0 padre jesuita, responsável pelas negociações de paz entre indios e portugueses, acolhe nos braços, solitário, o corpo de Aimberê; a imagem não fixa o combate que Ihe ocasionara a morte; seu sacrifício é associado ao cristão, seguindo a iconografia de uma pietá (Cavalcanti, 2007). Interessante comparar o quadro de Amoêdo ao do artista peruano Luis Montero (1826-1869), Os funerais de Atahualpa ${ }^{58}$, onde o templo inca, transformado em igreja católica, é invadido por mulheres que reclamam o corpo de Atahualpa, executado e submetido a rituais cristãos, marcando a violência e o estranhamento cultural (Amigo, 2001).

Praticamente no final do império, novo investimento será feito em torno da Independência do Brasil; era necessário lembrar, num momento de pressão republicana o quanto os brasileiros eram devedores da casa dos Bragança. Pedro Americo irá se responsabilizar pela execução de grande tela visando decorar o monumento do Ipiranga, dedicado à memória da Independência, originalmente a ser encomendada a um artista estrangeiro. Ao contrário de Moureau, que, quarenta anos antes, havia representado D. Pedro I em meio ao povo, Pedro Americo dará caráter solene e militar ao momento, apresentando o futuro imperador a cavalo, acompanhado de reduzido séquito civil, no alto de uma pequena colina, brandindo espada e sendo respondido em igual gesto por sua guarda de honra, sob a observação de alguns tropeiros apartados da cena.

A composição de Independência ou Morte ${ }^{59}$ (fig. 4) em muito se assemelha ao quadro de Jean-Louis Ernest Meissonier (1815-1891), 1807, Friedland ${ }^{60}$, assim descrito por 
3. Rodolpho Amoêdo, O último Tamoio, 1883. Óleo sobre lienzo, $181 \times 260 \mathrm{cms}$. Museu Nacional de Belas Artes, Rio de Janeiro/RJ.

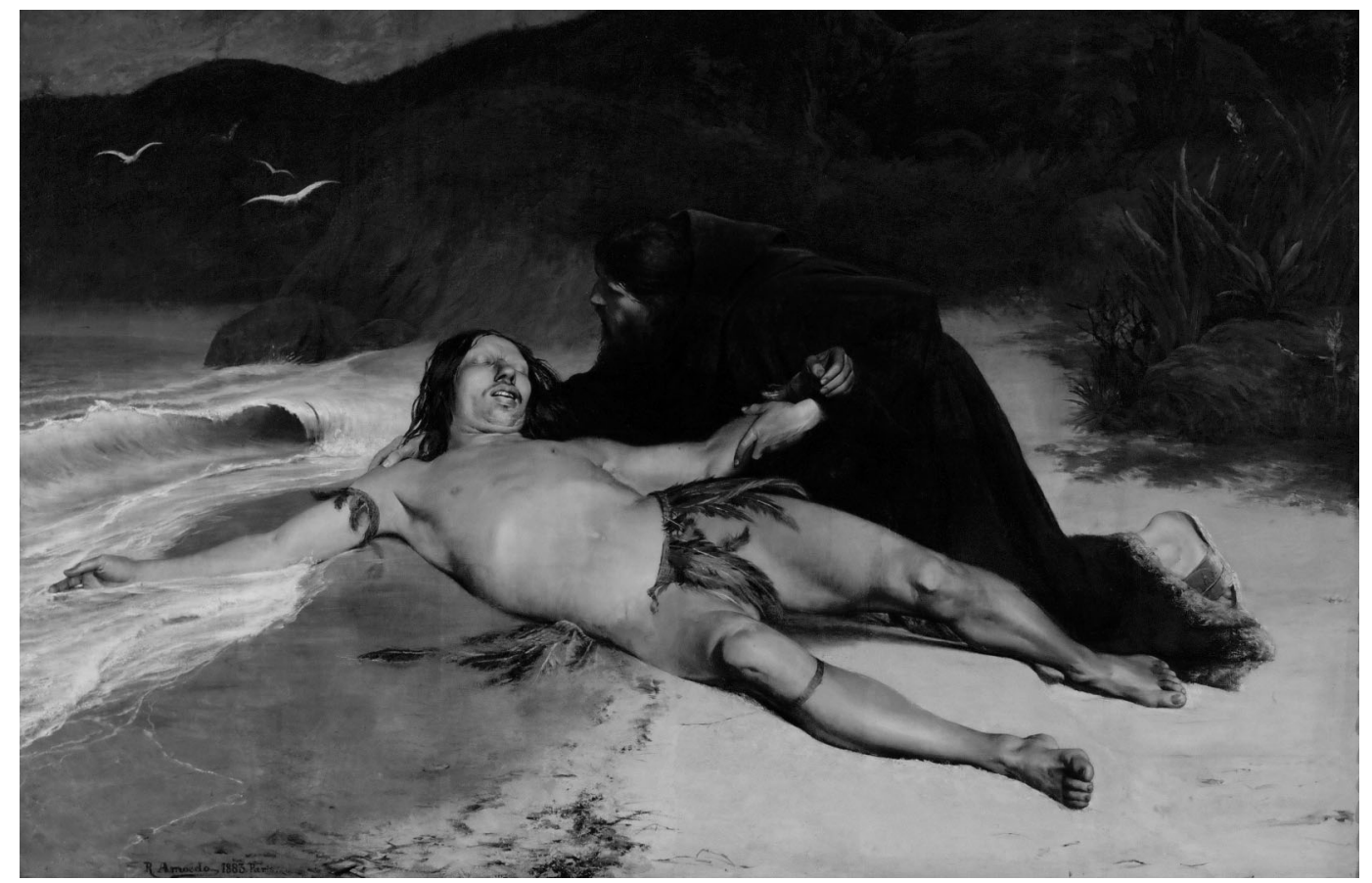

Octave Gréard, em 1897: "Le destin s'est fixé. Le monde tourne autour de Napoléon comme autour de son axe, L'Empereur est immobile au second plan; à ses pieds, un torrent d'hommes enivres par la gloire défilent en lui jetant leur âme" (Gréard, 1897, 252). Contudo, os quadros são diferentes. Em Meissonier, os soldados, correndo freneticamente na direção do observador, ao mesmo tempo que saúdam Napoleão, parecem abandoná-lo. Pedro Americo, todavia, recorre à composição elíptica, mais eficiente por integrar todos os personagens ao grupo principal, embora subvertendo levemente a perspectiva, em privilégio da unidade da ação6 ${ }^{61}$.

Como a Batalha do Avahy, Independência ou morte será pintada e exposta em Florença, contando com a presença de significativa platéia, a exemplo de D. Pedro II e da Imperatriz D. Tereza Cristina, das Rainhas da Sérvia e da Inglaterra, de professores da Academia das Belas Artes de Florença e de vários críticos (Oliveira, 1999). A tela posteriormente participará da Exposição Colombiana de Chicago, de 1893, integrando o palácio do governo brasileiro ${ }^{62}$. Intensamente reproduzido, Independência ou morte passou a ser o grande ícone da independência nacional brasileira.

Planejara-se também forte investimento em torno da abolição da escravatura, alcançada em virtude de lei sancionada pela Princesa Isabel, enquanto regente, em 13 de maio de 1888, após ser aprovada na Câmara e no Senado. Contando D. Pedro II idade avançada, preparava-se a imagem do Terceiro Reinado em torno da herdeira do trono, como a redentora dos escravos (Daibert Jr., 2004). A escravidão, reconhecida como mal necessário, era questão delicada para uma nação desejosa de ver-se civilizada e moderna. Com exceção dos artistas estrangeiros, que a abordaram ao retratarem a vida urbana e o exotismo tropical, os pintores brasileiros a ela não se reportaram ${ }^{63}$. Essa temática apenas entrará em pauta para glorificar o gesto da herdeira do trono $0^{64}$, representando-se, ao lado da Princesa Isabel, negros submissos e gratos. As rebeliões negras e o movimento abolicionista terão seu papel histórico negado. Pedro Americo preparava um grande quadro alegórico sobre o tema, enquanto Firmino Monteiro estudava representar o momento da assinatura da lei pela herdeira do trono, no 


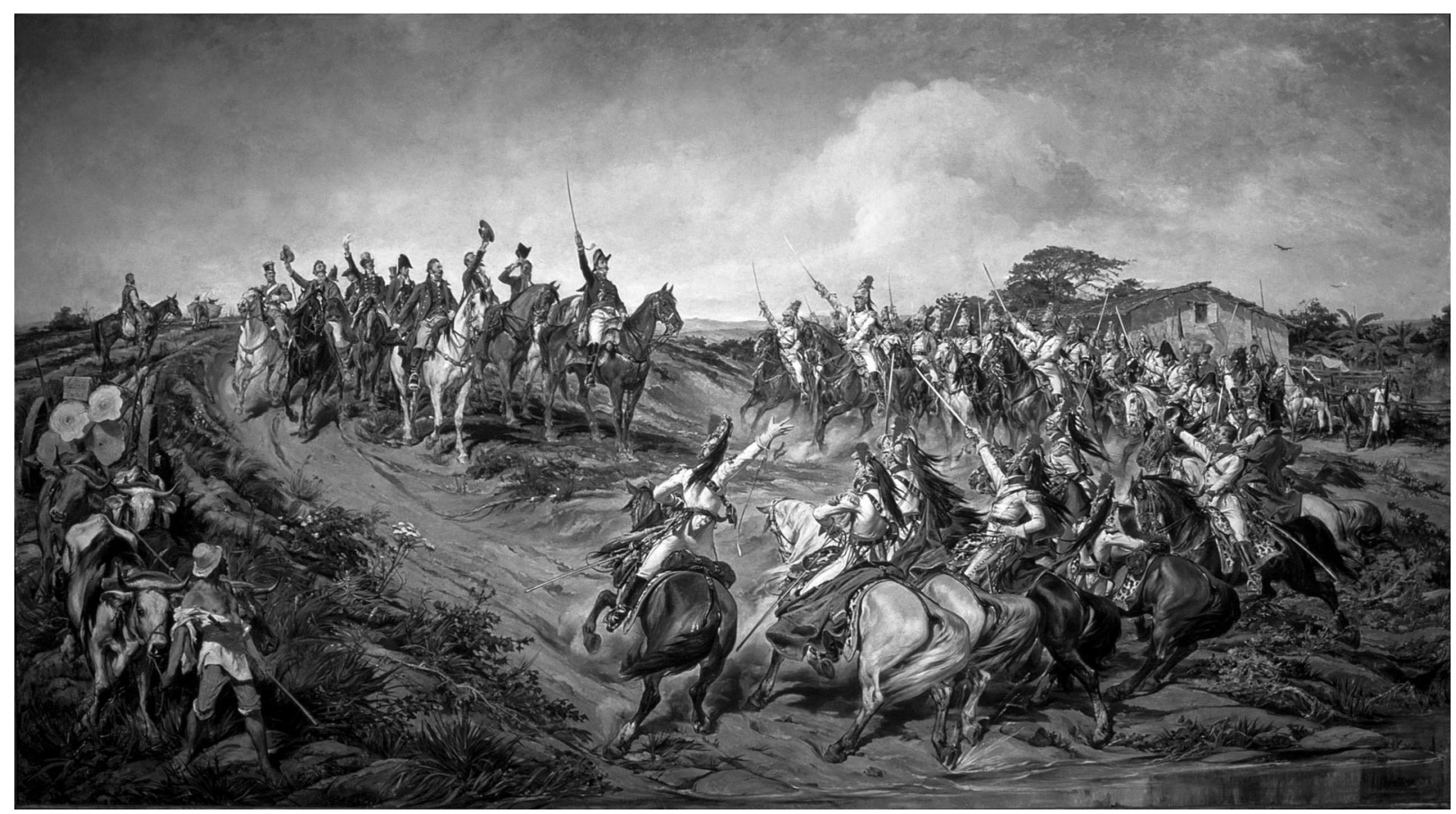

Senado ${ }^{65}$, quando a proclamação da República, ocorrida em 15 de novembro de 1889, abortou-Ihes os planos.

\section{República}

A República impunha aos artistas novas questões. A mais urgente era construir a versão oficial dos fatos, maximizar o papel dos atores principais e minimizar o acaso nos acontecimentos; fabricando novos heróis. A proclamação da República fora um golpe militar rápido, sem resistência e derramamento de sangue, sem muita articulação, desvinculado do movimento republicano civil. Nessa conjuntura, a versão dos fatos se sobrepunha aos acontecimentos e muitas foram as apresentadas (Carvalho, 1990). Os possíveis responsáveis pela República, Marechal Deodoro da Fonseca, Benjamin Constant, Quintino Bocaiúva e o Marechal Floriano Peixoto, cada qual encabeçando projetos diferentes de governo republicano, se revezavam nos monumentos públicos ${ }^{66}$. Henrique Bernardelli, atendendo à encomenda do Ministério da Guerra, executara, em 1890, retrato de Deodoro da Fonseca em grande formato, a cavalo, no ato de Proclamação da República, lembrando D. Pedro I representado por Pedro Americo. Entretanto, nenhuma imagem conseguiu se impor como ícone da Proclamação da República.

0 federalismo suscita a produção de iconografias locais, principalmente atendendo a decoração dos palácios dos presidentes dos estados. 0 que permitirá aflorar algo silenciado no Império: a memória das revoltas, tanto do período colonial, quanto da regência, ocorridas entre os governos de D. Pedro I e D. Pedro II. Foram muitas e, por vezes, reprimidas violentamente ${ }^{67}$. Nas Exposições Gerais de Belas Artes do período imperial, alusões às revoltas apareceram discretamente. Em 1841, chama-nos a atenção não uma pintura, mas alto-relevo em argila, de Zéphrin Ferrez, onde será representada A heróica fidelidade de Amador Bueno da Ribeira: cena inspirada na história colonial de São Paulo, 164168. A rebelião, fomentada por espanhóis, que aclama Amador Bueno da Ribeira rei de São Paulo, o qual jurara fidelidade ao Rei de Portugal, D. João IV, corresponde a exemplo de fato escolhido, demonstrativo da unidade en- 
tre metrópole e colônia, e não o contrário. Em 1843, João Maximiano Mafra (1823-1908) apresentou um retrato de Gonzaga, na prisão69. Tomás Antônio Gonzaga fora preso e exilado, acusado de ser o mentor intelectual de uma conspiração contra a metrópole portuguesa, em 1789, conhecida como Conjuração Mineira. Gonzaga nunca confessou sua participação no movimento, que, no início do século XIX, era apenas lembrado pela obra dos poetas nele envolvidos; por exemplo, os poemas de Gonzaga, escritos na prisão. Mafra o representa de forma semelhante à imagem conhecida do poeta romântico inglês Lord Byron, retratado por R. Westall ${ }^{70}$. Em 1876, com o movimento republicano já atuante, Leopoldino Joaquim Teixeira de Faria (18361911) expôs a Resposta de Joaquim José da Silva Xavier (Tiradentes) ao Desembargador Rocha, no ato da comutação de pena aos seus companheiros, depois da missa ${ }^{71}$. Trata-se de esboço do quadro, em execução, encomendado pelo governo de Minas Gerais, para decorar o salão da Assembléia Legislativa Estadual. Tiradentes também participara da Conjuração Mineira e fora o único a assumir a responsabilidade pela sedição e condenado à morte. Por defender idéias republicanas, foi escolhido pelo movimento republicano como herói nacional. Leopoldino de Faria o representa assemelhando-se a um filósofo, envolto em túnica, preso, interpelando autoridades, tornando-se rara apresentação impositiva do personagem (Milliet, 2001). Na Exposição Geral de 1884, última do período imperial, o tema das revoltas mostrou-se um pouco mais evidente. 0 próprio Leopoldino de Faria apresenta Auto de vistoria feito no cadáver do Desembargador Joaquim Nunes Machado: projeto de quadro para ser feito em tamanho natural, retratando o Deputado liberal Joaquim Nunes Machado, morto num dos combates do último movimento rebelde que marcou 0 processo de construção do Império, a Revolução Praieira, de 1848, em Recife. Nessa mesma exposição, a Conjuração Mineira volta a ser representada. Firmino Monteiro mostrou Alvarenga Peixoto no desterro, outro poeta participante da Conjuração Mineira preso e exilado; igualmente, Francisco Aurélio de Figueiredo e Melo, irmão de Pedro Americo, pintou 0 Tiradentes: estudo de cabeça. Aurélio de Figueiredo representa Tiradentes com cabelos e barbas longos, corda ao pescoço e olhos direcionados aos céus, como mártir cristão. Iconografia que será seguida e divulgada por Décio Villares, ao representar Tiradentes em litografia distribuída pela Igreja Positivista do Brasil, no ano de 1890, em que o dia da execução de Tiradentes, 21 de abril, foi declarado feriado nacional pela recém proclamada República.
Em 1893, surgirá uma representação ímpar do novo herói nacional. Pedro Americo, antigo pintor oficial do Império, agora aposentado da Escola Nacional de Belas Artes e Deputado Constituinte pela Paraíba, seu estado natal, pintara em Florença e expusera no Rio de Janeiro, em grande formato, o corpo esquartejado de Tiradentes sobre o cadafalso ${ }^{72}$ (fig. 5). A tela foi rechaçada pela crítica que a considerou desrespeitosa ao herói, por apresentá-lo aos pedaços (Christo, 2005).

Não era intenção de Pedro Americo pintar apenas o esquartejamento. 0 artista, baseando-se no livro História da Conjuração Mineira, de Joaquim Norberto de Souza Silva (Souza Silva, 1873), planejou executar cinco quadros, construindo uma narrativa sobre o tema em forma de tragédia: o herói seria punido por confiar nos poderosos da região mineradora, que iriam traí-lo, abortando a sedição

5. Pedro Américo. Tiradentes esquartejado, 1893. Óleo sobre lienzo, $270 \times 165 \mathrm{cms}$. Museu Mariano Procópio, Juiz de Fora/MG.

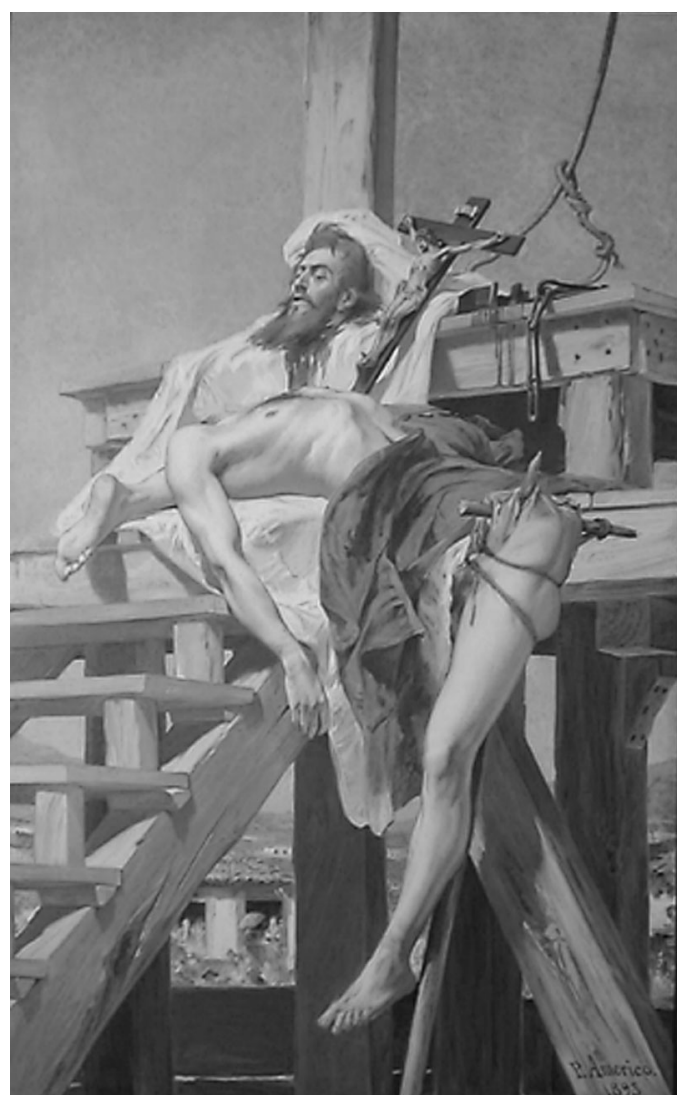


no nascedouro, antes mesmo da repressão. A narrativa enfatizaria a fragilidade interna do movimento e a ingenuidade de Tiradentes. Dos quadros esboçados, somente o último foi concluído.

Embora a tela isolada possa ser lida apenas como denúncia da repressão colonial, não pretende ser anedótica. Pedro Americo dignifica o herói ao reunir referências ao martírio cristão e à memória do movimento jacobino, pela aproximação com Marat assassinado ${ }^{73}$, de Jacques Louis David. Entretanto, fixando-se no esquartejamento, o artista impede a associação levada a efeito pelo movimento republicano entre Conjuração Mineira, Independência e a própria República. 0 quadro congela a morte e impede a "ressurreição" dos ideais do herói.

A representação anti-heróica de Tiradentes não foi aceita, acarretando longo silêncio sobre a obra, que não circulou como imagem, litografada ou fotografada, não ilustrou livros sobre a História do Brasil, permanecendo esquecida, por mais de meio século, num museu do interior do país. Aurélio de Figueiredo irá propor, no mesmo ano, outra representação para a morte de Tiradentes, apresentando-o em seu momento máximo, vivo e calmo diante da morte; resignadamente cristão. Imagem largamente difundida, quase oficial.
Interessante observar que, em 1893, um dos dois quadros de Aurélio de Figueiredo sobre Tiradentes, provavelmente a representação da cabeça assemelhando-se a Cristo, participou da Exposição Universal Colombiana de Chicago (Bancroft, 1893, 917-8), onde Leandro Izaguirre apresentará a Tortura de Cuauhtémoc ${ }^{74}$, cujo herói, personificando a resistência do povo mexicano, encara dignamente os algozes. A aproximação das duas obras torna mais evidente o caminho oposto seguido pelos artistas brasileiros, Pedro Americo e Aurélio de Figueiredo, negando ao herói nacional o enfrentamento e a indignação.

No império, buscou-se a afirmação da unidade nacional, representando as vitórias brasileiras sobre o inimigo externo, silenciando, entretanto, quanto às revoltas internas. $\mathrm{Na} \mathrm{Re-}$ pública, as últimas serão representadas sem o poder de uma convicção coletiva; Tiradentes-mártir será a única imagem realmente a impor-se, contaminando representações de outras revoltas, privilegiando a idéia do herói-vítima.

0 final do século e as primeiras décadas do seguinte assistirão ao enfraquecimento da pintura de história; pedagógica, episódica, individual, decorando palácios legislativos, tribunais e teatros, terá alcance bem mais limitado (Coli, 2003), apesar de numericamente superior à produção do século XIX.

\section{NOTAS}

1 Jean-Maurice de Nassau-Siegen (1604-1679), capitão-general das possessões holandesas no Brasil de 1636 a 1644.

2 Batalhas dos Guararapes: combates travados em 19 de abril de 1648 e 19 de fevereiro de 1649, em Pernambuco, entre luso-brasileiros e batavos, constituindo-se num momento decisivo para a expulsão dos holandeses que invadiram o nordeste brasileiro entre 1630 e 1654.

30 primeiro conjunto foi encomendado em 1709, para ser exposto na Câmara do Senado de Olinda. São dois painéis sobre as batalhas dos
Montes Guararapes e outro alusivo à batalha dos Montes das Tabocas (1645). Os três quadros, atualmente, encontram-se no Museu do Estado de Pernambuco. 0 segundo conjunto data de 1800, pertencente à Igreja de Nossa Senhora dos Prazeres dos Montes Guararapes, fora encomendado ao mestre-pintor José da Fonseca Galvão. Os dois painéis alusivos às batalhas dos Montes Guararapes integram atualmente o acervo do Instituto Arqueológico Histórico e Geográfico Pernambucano. A pintura do forro do coro da Igreja de Nossa Senhora da Conceição dos Militares, no Recife, atribuida inicialmente a João de Deus Sepúlveda, e, segundo

Aceptado: 15 de mayo de 2008 
estudos mais recentes, a José de Oliveira Barbosa, encomendada pelo Governador José César de Menezes, em 1781, representa a primeira Batalha dos Guararapes, travada em 1648. A segunda batalha dos Guararapes fora pintada duas décadas antes, em 1758, por artista anônimo, em Portugal, tendo sido doada ao Museu Histórico Nacional, em 1940.

4 A primeira referência que tivemos sobre os sete painéis, e não três como conheciamos antes, devemos à reportagem do jornalista-historiador Leonardo Dantas Silva, publicada 27 de Janeiro de 2004, no Diário de Pernambuco.

5 Outros painéis devocionais relatam episódios da luta contra os holandeses, como o painel da Igreja de São Cosme e Damião, município de Igaraçu, Pernambuco, onde a história da cidade é narrada, protegida da peste e dos holandeses pelos referidos santos. Também é possivel encontrar referências a outros momentos da história da colônia em ex-votos individuais, como o Ex-voto de Agostinho Pereira da Silva. Pintura existente na Ermida de Nossa Senhora do Monte Serrate, em Salvador (óleo sobre tela, $110 \times 126 \mathrm{~cm})$, executada em 1743, por autor anônimo, apresenta as vicissitudes por que passa Agostinho Pereira da Silva, inclusive no periodo conhecido como a Guerra dos Emboabas, caracterizada por conflitos armados ocorridos entre os anos de 1707-1709, na região central de Minas Gerais, onde foram descobertas as primeiras minas de ouro.

6 A exemplo de Jean-Baptiste Vermay, que se exilou em Cuba, abrindo uma escola de desenho em 1818, depois transformada na Academia de Artes de Havana. Ver: Histoire de l'Expansion de l'art français. Le mon- de latin. Paris: Henri Laurens, éditeur, 1933, pp. 339-340; citado por (Dias, 2005).

$7 \mathrm{Em}$ tese recentemente defendida, Elaine Dias esclarece as negociações entre Lebreton e a corte portuguesa, objetivando a vinda de artistas franceses para o Brasil, a partir de novos documentos encontrados no Arquivo Nacional da Torre do Tombo, em Lisboa. Os estudos anteriores não tinham clareza sobre o autor da iniciativa que culminou na formação da Missão Artística Francesa (Dias, 2005).

8 Jean-Baptist Debret, Napoléon rend hommage au courage malheureux, 1806, óleo sobre tela, $390 \times 621 \mathrm{~cm}$, Versailles.

9 Óleo sobre tela, $12 \times 64 \mathrm{~cm}$. pertencente ao Museu Imperial de Petrópolis, Rio de Janeiro.

10 Sobre a pintura de história de Debret destacamos a dissertação de mestrado de Elaine Dias (Dias, 2001).

11 Desembarque de D. Leopoldina no Brasil, aquarela monocromática (sépia), Coleção Museus Castro Maya, Rio de Janeiro, e água-forte colorida, 21,6 × 30,1 cm., Biblioteca Nacional, Rio de Janeiro.

12 Estudo para o desembarque de $D$. Leopoldina no Brasil, óleo sobre tela, $44,5 \times 69,5$ cm., Museu Nacional de Belas Artes, Rio de Janeiro.

13 Aquarela/sépia, 30,5 × 23 cm., Coleção Museus Raymundo Ottoni de Castro Maya, Rio de Janeiro.

14 Aquarela, Coleção Museus Castro Maya.

15 Óleo sobre tela, $60 \times 42 \mathrm{~cm}$., Museu Nacional de Belas Artes, Rio de Janeiro.

16 Óleo sobre tela, $277 \times 194 \mathrm{~cm}$., Museu do Louvre.

17 Óleo sobre tela, $278 \times 196 \mathrm{~cm}$., Versailles.
18 Aquarela, Coleção Museus Castro Maya.

19 Esboço para aclamação de Dom Pedro I, óleo sobre tela, $46 \times 69 \mathrm{~cm}$., Museu Nacional de Belas Artes, Rio de Janeiro.

20 Palácio Itamaraty, Brasília.

21 Jacques-Louis David, Sacre de l'empereur Napoléon ler et couronnement de l'impératrice Joséphine dans la cathédrale de Notre-Dame de Paris, óleo sobre tela, $610 \times 931 \mathrm{~cm}$. Museu do Louvre.

22 A obra de Debret no Brasil possui vasta bibliografia. Destacamos a tese de doutorado de Valéria Lima (Lima, 2003). Sua versão resumida foi publicada pela editora Jorge Zahar, em 2004, com o título: Uma viagem com Debret.

23 Também é possivel encontrar a grafia "Moreaux" para o sobrenome desse artista.

240 ato de coroação do Imperador $D$. Pedro I, 238 × 310, Museu Imperial de Petrópolis.

25 Grandes Chroniques de France, enluminées par Jean Fouquet, Tours, vers 1455-1460, Paris, BnF, département des Manuscrits, Français, 6465, fol. 89v. (Second Livre de Charlemagne).

26 Coroação de D. Pedro II, óleo sobe tela, $743 \times 485 \mathrm{~cm}$, Instituto Histórico e Geográfico Brasileiro, Rio de Janeiro.

27 François Gérard, Sacre de Charles X à Reims, 1825-29, óleo sobre tela, 514 $\times 972 \mathrm{~cm}$, Versailles.

28 Proclamação da Independência, 244 $\times 383 \mathrm{~cm}$., Museu Imperial de Petrópolis.

29 Alguns atribuem a referida tela a seu irmão mais novo, que com ele veio da França, Louis-Auguste Moreau. Baseamo-nos em (Duque, 1995, 105).

30 Antoine-Jean Gros, Bonaparte visitant les pestiférés de Jaffa, 11 mars 
1799, 1804. Óleo sobre tela, $523 \times$ $715 \mathrm{~cm}$. Paris, Museu do Louvre.

31 Outro quadro produzido no Brasil, sobre a epidemia do cólera, retrata o vice-presidente do Pará visitando sua cidade natal, Cametá, atingida pela epidemia. A tela "Cólera Morbus" (c. 1858), pintada por Constantino Pedro Chaves da Motta, encontrase no museu da cidade de Cametá em péssimo estado de conservação (Farias, 2007).

32 Juan Manuel Blanes. Un episodio de la fiebre amarilla en Buenos Aires, óleo sobre tela, $230 \times 180 \mathrm{~cm}$, Museo Nacional de Artes Visuales, Montevideo, Uruguay.

33 Sobre essa obra ver a análise de (Malosetti Costa, 2001, 65-81).

34 Sobre a AIBA ver (Lima, 1994; Fernandes, 2001; Dias, 2005).

35 Texto de apresentação da tela no catálogo da exposição de 1841: 0 Governador Geral, querendo arruinar as possessões holandesas, deu ordem aos seus mestres de campo na Várzea, que pusessem fogo a todas as plantações da cana em Pernambuco, não refletindo que os portugueses, e não os holandeses, estavam senhores do pais, e que este ato ia destruir todos os recursos do exército patriota: existiam então na Província cento e cinqüenta fazendas e engenhos de açúcar que empregavam 3.750 homens. Vieira ficou tão atônito ao receber esta ordem absurda que não a quis referendar: mas, para dar um testemunho de obediência, fez por fogo aos seus próprios canaviais, sofrendo uma perda de duzentos mil cruzados (Levy, 1990. 33).

36 Ver comentário mais adiante.

37 Texto de apresentação da tela no catálogo da exposição de 1848: $\mathrm{Na}$ guerra que os holandeses moveram ao Brasil de 1623 a1638, esta ge- nerosa matrona depois de perder nos combates três filhos e um genro, cinge a espada a dois meninos que the restavam, um de cartoze anos, e treze, para irem por sua vez defender sua pátria e religião. Veja-se Freire de Andrade (Levy, 1990, 85).

38 Victor Meirelles, Primeira missa no Brasil, óleo sobre tela, $260 \times 356$ $\mathrm{cm}, 1860$, Museu Nacional de Belas Artes, Rio de Janeiro.

39 Sobre Victor Meirelles ver (Coli, 2005; Coli, 1997).

40 Horace Vernet, Première messe en Kabylie, 1854, óleo sobre tela, $195 \times$ $123 \mathrm{~cm}$, Musée Cantonal des BeauxArts, Lausanne, França.

41 Juan Bautista Vermay, La primera misa, 1826, El Templete, Havana, Cuba; Louis-Philippe Hébert, The first mass celebrated in Montréal, in May 1642. Baixo-relevo em bronze. Detalhe do monumento a Paul de Chomedey, de Maisonneuve, 1895, Place d'Armes, Montreal, Canadá; Pedro Subercaseaux Errázuriz, Primera Misa en Chile, 1904, Museo Historico Nacional, Santiago, Chile; José Bouchet, La primera misa en Buenos Aires, 1910, Museo Historico Nacional, Buenos Aires, Argentina.

42 Oscar Pereira da Silva, Fundação da cidade de São Paulo, 1909, Museu Paulista; Antônio Parreiras, A primeira missa de São Paulo de Piratininga, 1913. Rodolpho Amoedo, Fundação da Cidade do Rio de Janeiro, 1925.

43 Victor Meirelles, Batalha dos Guararapes, óleo sobre tela, $500 \times 925$ $\mathrm{cm}, 1879$, Museu Nacional de Belas Artes, Rio de Janeiro.

44 Varnhagen, 2002 (1.a edição, ainda na forma de um ensaio: 1871). Sobre a relação entre o quadro de Victor Meirelles e o livro de Varnhagen ver (Castro, 2007).
45 Dos artigos relativos à história publicados na Revista do IHGB, ao longo do século XIX, 14\% dedicavam-se ao período da Guerra do Paraguai. Ver Poppino, Rollie E., "A Century of the Revista do Instituto Histórico e Geográfico Brasileiro", The Hispanic American Historical Review, Durham: 33 (2), pp. 307-32, maio, 1953. Citado por (Castro, 2007, 56).

460 quadro exposto, hoje, no Museu Histórico Nacional, no Rio de Janeiro, é uma réplica da obra original (óleo sobre tela, 4,60 × 8,20 m.). A primeira versão participou da Exposição Universal da Filadélfia, em 1876, e, na volta, uma sucessão de erros no seu transporte ocasionaram a sua deterioração.

47 Victor Meirelles, Passagem de Humaitá. 1869-72, Óleo sobre tela, 2,68 × 4,35 m, Museu Histórico Nacional.

48 Vale lembrar a observação de Walter Luiz Pereira sobre o destaque diferenciado dado pelo Museu Histórico Nacional à tela Combate Naval de Riachuelo (Pereira, 2003).

49 Pedro Americo, Batalha de Campo Grande, 1871. Óleo sobre tela, 530 $\times 332$ cm., Museu Imperial de Petrópolis.

50 Carta de Alfredo Taunay a Pedro Americo, de Curugnaty, datada de 22 de Dezembro de 1869. Pasta M149, Arquivo, Museu Imperial de Petrópolis.

51 Pedro Americo, Batalha de Avahy, óleo sobre tela, $600 \mathrm{~cm} \times 100 \mathrm{~cm}$., Museu Nacional de Belas Artes, Rio de Janeiro.

52 Outras obras apresentadas nas Exposições Gerais no Segundo Império sobre a Guerra do Paraguai: 1865, Antônio Araújo de Souza Lobo, Passeio dos Voluntários da Pátria pelas ruas do Rio de Janeiro depois da primeira reunião no Teatro Lírico (esboço), Ar- 
sênio Cintra da Silva, Ataque à praça de Paissandú pelo Capitão Peixoto no dia 6 de dezembro de 1864 (esboço); 1866, Francisco Manoel Chaves Pinheiro, Modelo colossal de uma estátua eqüestre, representando Sua Majestade o Imperador em Uruguaia"; 1868, Antônio Araújo de Souza Lobo, Tomada do forte de Itapirú pelas tropas brasileiras: campanha do Paraguai; 1870, Antônio Araújo de Souza Lobo, Bombardeamento do forte de Itapirúpelo encouraçado Tamandaré, Edoardo de Martino, Passagem de Humaitá por uma divisão da esquadra brasileira na noite de 19 de fevereiro de 1868; Joaquim da Rocha Fragoso, Retrato do General Osório, Marquês de Herval, Retrato do General Duque de Caxias, Retrato do Almirante Visconde de Inhaúma, Retratos dos três valentes irmãos Fonseca mortos na Guerra do Paraguai. 1872, Francisco de Azevedo Monteiro Caminhoá e Paul Bénard, Desenho do modelo de um monumento que deve ser erigido no Campo da Aclamação em memória das vitóricas alcançadas no Paraguai pelas armas brasileiras, Ulrich Steffen, Batalha de Caraguatai no Paraguai a 6 de Setembro de 1869, Francisco de Azevedo Monteiro Caminhoá e Paul Bénard, Monumento patriótico do Brasil em memória de nossas vitórias no Paraguai, tendo de altura 60 metros, destinado a ser erigido no centro do ajardinamento do Campo da Aclamação (fotogravura), Projeto de monumento em memória da Batalha de Riachuelo, tendo de altura 16 metros (fotografia); 1876, Leopoldino Joaquim Teixeira de Faria, Campanha do Paraguai: tomada da Ponte de Itororó pelo intrépido Duque de Caxias, auxiliado pelos valentes Generais Argolo e Gurjão, e pelo Coronel Fernandes Machado (esboço), Pedro Americo de Figueiredo e Melo, Campanha do Paraguai: passagem do Passo da Pátria pelo General Osório, Marquês do Herval (esboço), Onze bustos de mármore do Imperador, do Conde d'Eu e de generais e almirantes, oferecidos pelo governo português e executados por Victor Bastos, Simões de Almeida e Soares dos Reis (portugueses), Cesar Sighinolfi (italiano), A. Calmels (francês). 1879, Cândido Caetano de Almeida Reis, Busto do Excelentíssimo Senhor Marquês do Heval, N. Panini, Episódio da Guerra do Paraguai. Combate de 19 de fevereiro de 1868, no reduto do estabelecimento sob o comando do General Andrade Neves, Barão do Triunfo; 1884, Antônio Firmino Monteiro, Um episódio da retirada da Laguna. Uma mulher apanha a clavina do marido, morto, e, disparando-a por vezes, defende a vida de um filho (Taynay, Narrativas Militares) (Levy, 1990).

53 Existem duas versões praticamente iguais para essa obra: uma, de $100 \times$ $80 \mathrm{~cm}$., pertence ao Museu Nacional de Artes Plásticas, Montevidéu, Uruguai; outra, de $61,4 \times 51,4 \mathrm{~cm}$., que integra a Coleção Porcel, em Buenos Aires, Argentina.

54 Cándido López pintou mais de 50 telas num registro minucioso e singeIo, José Ignacio Garmendia produziu o Álbum de la guerra del Paraguay, contendo aquarelas realizadas a partir de fotografias, e Adolfo Methfessel realizou uma série de pequenos óleos e aquarelas. Ver: (Pacheco, s/d.; José, 2005; Tobler/Lopacher, 1969).

55 Particularmente as obras de Félix Parra, Joaquín Ramírez e Leandro Izaguirre (Reyes Fragoso, 2003).

56 Obras sobre temática indigenista que participaram das Exposições Gerais no império: 1860: Frederico Tirone, Enterro de Atalá, Fuga de Atalá;
1862: Jules Le Chevel, Paraguassú e Diogo Álvares Correa; 1866: Victor Meirelles, Moêma; 1879: Firmino Monteiro, Exéquias de Camorim, 1884: Augusto Rodrigues Duarte, Exéquias de Atalá (também apresentada na Exposição Universal de Paris em 1878), Aurélio de Figueiredo, Ceci no banho, José Maria de Medeiros, Iracema, Rodolpho Amoêdo, 0 último Tamoio, Marabá (Levy, 1990).

57 Rodolpho Amoêdo, 0 último Tamoio, 1883, óleo sobre tela, $180 \times 261 \mathrm{~cm}$. Museu Nacional de Belas Artes.

58 Luis Montero, Los funerales de Atahualpa, 1864-1867, óleo sobre tela, $350 \times 430 \mathrm{~cm}$. Museu de Arte de Lima, Perú.

59 Pedro Americo, Independência ou morte!, 1888, $760 \times 415 \mathrm{~cm}$., Museu Paulista, USP.

60 Ernest Meissonier, 1807, Friedland, 1875, óleo sobre tela, $144 \times 252 \mathrm{~cm}$. Metropolitan Museum of Art.

61 Os estudos para o quadro foram apresentados na Exposição Universal, em Paris, de 1889. Segundo seu biógrafo, teriam sido admirados pelo próprio Meissonier, então presidente do júri internacional de Belas Artes (Oliveira, 1943, 163-164).

62 "In addition to the Brazilian collection in the palace of Fine Arts there is one of equal merit in the government building, including Pedro Americo's famous painting of the 'Proclamation of Brazilian Independence' by the emperor in 1822" (Bancroft, 1893, 917-8).

63 Embora nos periódicos ilustrados representações da escravidão sejam uma constante.

64 As representações anteriores dizem sempre respeito à magnitude das ações de governo direcionadas para o término gradativo da escravidão. Sobre esse tema participaram das 
Exposições Gerais do império: 1872: Francisco José Pinto Carneiro, Alegoria à lei de 28 de setembro de 1871 relativa à emancipação do elemento servil. Reverso de uma medalha gravada na Casa da Moeda e oferecida pelo Grande Oriente do Brasil ao Visconde do Rio Branco; 1884: Emile Rouéde, Navio negreiro fugindo de um navio de guerra brasileiro. Na fuga atira ao mar a sua carga humana: do navio brasileiro descem escaleres de salvação, Estevão Roberto da Silva, A lei de 28 de setembro de 1871 esboceto (Levy, 1990). Em 1885, Pedro Peres pintou a Primeira Emancipação Municipal, representando a Princesa Isabel concedendo cartas de alforria (acervo da Câmara Municipal do Rio de Janeiro).

65 Pedro Americo, Painel da libertação dos escravos (estudo), 1889, 140,5 $\times$ $20 \mathrm{~cm}$. Acervo Artístico e Cultural dos Palácios do Governo do Estado de São Paulo. Coleção Palácio dos Bandeirantes. Antônio Firmino Monteiro, 13 de maio (esboço), s/d, Coleção Francisco Marques dos Santos, Rio de Janeiro.

66 Monumento a Benjamin Constant, de Décio Villares, Rio de Janeiro (proposto em 1892 e executado em 1925); Monumento a Floriano Peixoto, de Eduardo de Sá, Rio de Janeiro (proposto em 1901 e executado em 1910); Monumento a Deodoro da Fonseca, de Modestino Kanto, 1937 (Leal, 2006).

67 A exemplo de: Revolta da Cachaça (1660), Revolta de Beckman (1684), Guerra dos Emboabas (1708), Revolta do Maneta (1711), Revolta de Felipe dos Santos (1720), Conjuração Mineira (1789), Conjuração Fluminense (1794), Revolta dos Alfaiates (1798), Revolução de 1817, Revolta dos Malês (1835) e Praieira Pernambucana (1848).
68 Texto de apresentação da tela no catálogo da exposição: Chegando a São Paulo a notícia da aclamação de Dom João IV em 1640, Os espanhóis estabelecidos naquela província, para roubarem ao menos à Coroa Portuguesa uma parte do Brasil, se lembraram de aclamar rei a Amador Bueno da Ribeira, chegando a ameaçá-lo com morte se não quisesse empunhar o cetro. Sai este da sua casa com a espada nua na mão contrastando com gritos de lealdade aos gritos dos sediciosos, e corre a refugiar-se no Mosteiro de são Bento, onde ajudado pelo Dom Abade, seus religiosos e pessoas de consideração que mandara avisar, confunde os conspiradores, e faz compreender aos iludidos que o reino pertencia à Casa de Bragança, e que dele se acharia em posse pacífica se a violência da ocupação espanhola não houvesse sufocado o seu direito (Levy, 1990, 35).

69 Hoje desaparecido, o quadro esteve presente na IV Exposição Geral de Belas Artes, de 1843, na seção de Pintura, sala 9, sob o número 0015/053, acompanhado da seguinte informação: "Tomás Antônio Gonzaga. Natural de Pernambuco (sic), o autor de Marilia de Dirceu, conspirando com outros ilustres filhos do Brasil em prol da sua independência, é preso e encerrado na Fortaleza de Santa Cruz. O poeta acaba de escrever uma de suas imortais liras, e parece meditar em outra" (Levy, 1990, 47).

70 Frieiro, Eduardo, O diabo na livraria do cônego; Como era Gonzaga? e Outros

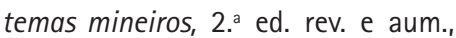
São Paulo, Ed. Itatiaia: Ed. USP, 1981, p. 72. Ver (Christo, 2007, 11-57).

71 Leopoldino de Faria, A resposta de Tiradentes ao Desembargador Rocha, no ato da comutação da pena aos companheiros depois da Missa, c.
1884. Óleo sobre tela, Câmara Municipal de Ouro Preto.

72 Pedro Americo, Tiradentes esquartejado, 1893. Óleo sobre tela, $270 \times$ 165 cm., Museu Mariano Procópio, Juiz de Fora.

73 Jacques-Lois David, Marat assassiné, 1793. Óleo sobre tela, $165 \times 128$ cm., Musée Royaux des Beaux-Arts, Bruxelles.

74 Leandro Izaguirre, Tortura de Cuauhtémoc (1893), óleo sobre tela, 2,95 $\times$ 4,56 m; Museu Nacional Nacional de Arte, Cidade do México. Ver: (Catálogo, 2002, 329-342).

\section{BIBLIOGRAFÍA}

Amigo, Roberto (2001): Tras un Inca, Buenos Aires, Fundación para la Investigación del Arte Argentino.

Bancroft, Hubert Howe (1893): The Book of the Fair: an historical and descriptive presentation of the world's science, art, and industry, as viewed through the Columbian Exposition at Chicago in 1893, designed to set forth the display made bythe Congress of $\mathrm{Na}$ tions, of human achievement in material form, so as to more effectually to illustrate the profess of mankind in all the departments of civilized life, Chicago, San Francisco, The Bancroft Company, $10 \mathrm{v}$.

Bandeira, Manuel (1967): Poesia completa e prosa, Rio de Janeiro, José Aguilar ed.

Belluzzo, Ana M. de M. (1994): O Brasil dos viajantes, São Paulo, Odebrecht.

Belluzzo, Ana M. de M. (org.) (1988): Edoardo de Martino, pintor e marinheiro, São Paulo, Companhia São Paulo de Petróleo/Pancrom.

Brown, Jonathan (2000): Pintura na Espanha, 1500-1700, São Paulo, Cosac \& Naify. 
Carvalho, José Murilo de (1990): A formação das almas; o imaginário da República no Brasil, São Paulo, Companhia das Letras.

Castro, Isis Pimentel de (2007): Os pintores de História. A relação entre arte e história através das telas de batalha de Pedro Américo e Victor Meirelles (Dissertação de mestrado, UFF).

Catálogo comentado del acervo del Museo Nacional de Arte (2002), Pintura, siglo XIX, Tomo I, México, Instituto Nacional de Bellas Artes.

Cavalcanti, Ana Maria Tavares (2007): "0 último tamoio e o último romântico", Revista de História da Biblioteca $\mathrm{Na}$ cional. Rio de Janeiro, Sociedades de Amigos da Biblioteca Nacional, Ano 3, n. ${ }^{\circ} 26$, nov. pp. 64-69.

Christo, Maraliz de C. V. (2007): "As fontes literárias da narrativa de Pedro Americo sobre a Conjuração Mineira", en Borges, Célia Maia (org.), Narrativas e imagens, Juiz de Fora, Ed. UFJF, pp. 11-57.

Christo, Maraliz de C. V. (2005): Pintura, história e heróis: Pedro Americo e "Tiradentes esquartejado", Campinas (Tese de doutoramento em História, UNICAMP).

Christo, Maraliz de C. V. (2007): "Victor Meirelles, Pedro Americo e Henrique Bernardelli: outras leituras", Christo, Maraliz de C. V. (org.). "Dossiê Pintura de História". Anais do Museu Histórico Nacional, Rio de Janeiro, MHN, v. 39, pp. $169-188$

Coli, Jorge (2003): "Depois do Império - as artes na primeira década da república brasileira". ArtCultura - Núcleo de Estudos em História da Arte e da Cultura. Uberlândia, UFU v. 5, n. 6, pp. 7-17.

Coli, Jorge (2002): "O sentido da batalha: Avahy, de Pedro Americo", Projeto História (artes da história \& outras linguagens), São Paulo, PUC-São Paulo, n. 24, junho, p. 113-128.
Coli, Jorge (2005): Como estudar a arte brasileira do século XIX, São Paulo, Editora SENAC.

Coli, Jorge (1997): Victor Meirelles e a pintura internacional, Campinas (Tese de livre docência, UNICAMP).

Daibert Jr., Robert (2004): Isabel, a "Redentora" dos escravos: uma história da princesa entre olhares negros e brancos (1846-1988), Bauru, SP, ED.USC.

Debret, Jean-Baptiste (1989): Viagem Pitoresca e Histórica ao Brasil, Tomo I, Belo Horizonte, Ed. Itatiaia Ltda; São Paulo, Ed. da Universidade de São Paulo.

Dias, Elaine (2001): Debret, a pintura de história e a ilustração da corte $d a$ Viagem Pitoresca e Histórica do Brasil, Campinas (Dissertação, Mestrado em História, UNICAMP).

Dias, Elaine (2005): Félix-Émile Taunay: cidade e natureza no Brasil, Campinas (Tese, doutorado em História, UNICAMP).

Dias, Elaine (2006): "A representação da realeza no Brasil: uma análise dos retratos de D. João VI e D. Pedro I, de Jean-Baptiste Debret", Anais do Museu Paulista: História e Cultura Material, São Paulo, USP, Museu Paulista, v. 14, n.1, jan./jun., pp. 243-262.

Duque, Gonzaga (1995): A arte brasileira, Rio de Janeiro, H. Lombaerts \& Cia., 1888, ed. Aos c. de T. Chiarelli, Campinas, Mercado de Letras.

Farias, Edison (2007): "Tramas e dramas sobre a tela de Constantino da Motta", en 19\&20 - A revista eletrônica de DezenoveVinte, Volume II, n. 2, abril de. Disponivel no site: http://www.dezenovevinte.net/, consultado em 24 de novembro de 2007

Fernandes, Cybele Vidal Neto (2001): Os caminhos da arte, o ensino artístico na Academia Imperial das Belas Artes - 1850/1890, Rio de Janeiro (tese de doutoramento, História Social UFRJ).
Gréard, Octave (1897): Meissonier, ses souvenirs, ses entretiens, Paris, Hachette.

Guarilha, Hugo Xavier (2005): A questão artística de 1879: polêmica da crítica de arte no segundo reinado, Campinas (Dissertação, Mestrado em História da Arte, UNICAMP).

Guimarães, Lúcia M. P. (1995): "Debaixo da imediata proteção de Sua Majestade Imperial. 0 Instituto Histórico e Geográfico Brasileiro (1838-1889)", RIHGB, Rio de Janeiro, n. 388.

Guimarães, Manuel L. S. (1988): "Nação e civilização nos trópicos: o IHGB e o projeto de uma história nacional", Estudos Históricos, Rio de Janeiro, I (I): 5-27.

Gutiérrez, Ramón \& Gutiérrez Viñuales, Rodrigo (2006): América y España, imágenes para una historia; independencias e identidad 1805-1925, Madrid, Fundación MAPFRE.

Leal, Elisabete da Costa (2006): Filósofos em tintas e bronze: arte, positivismo e política na obra de Décio Villares e Eduardo de Sá, Rio de Janeiro (Tese de Doutoramento, História, UFRJ).

Levy, Carlos Roberto Maciel (1990): Exposições Gerais da Academia Imperial e da Escola Nacional de Belas Artes, Período Monárquico. Catálogo de artistas e obras entre 1840 e 1884, Rio de Janeiro, Edições Pinakotheke.

Lima, Valéria Alves Esteves (1994): A Academia Imperial das Belas-Artes: um projeto político para as artes no Brasil, Campinas (Dissertação de Mestrado, UNICAMP).

Lima, Valéria (2003): A Viagem Pitoresca e Histórica de Debret: por uma nova leitura (Tese de Doutoramento, UNICAMP).

Lima, Valéria (2004): Uma viagem com Debret, Rio de Janeiro, Zahar.

Malosetti Costa, Laura (2001): Los primeros modernos; arte y sociedad en Buenos 
Aires a fines del siglo XIX, Buenos Aires, Fondo de Cultura Económica de Argentina.

Martius, Karl Friedrich Philipp von (1845): "Como se deve escrever a História do Brasil?", Revista do Instituto Histórico e Geográfico Brasileiro, Rio de Janeiro, 6 (24): 381-403, Jan.

Mattos, Cláudia Valladão de (2007): Artistas viajantes nas fronteiras da História da Arte, Comunicação apresentada no III Encontro de História da Arte do IFCH, UNICAMP (inédito).

Mello Jr., Donato (1982): "Temas históricos", en Rosa, Ângelo de Proença e outros, Victor Meirelles de Lima, 18321903, Rio de Janeiro, Edições Pinakotheke, pp. 55-102.

Milliet, Maria Alice (2001): Tiradentes: o corpo do herói, São Paulo: Martins Fontes.

Oliveira, Cecília Helena de Salles e Mattos, Cláudia Valladão de (1999): brado do Ipiranga, São Paulo, EDUSP.

Oliveira, J. M. (1943): Cardoso de. Pedro Américo sua vida e suas obras, Rio de Janeiro, Imprensa Nacional.

Pacheco, Marcelo E. (s/d.): Candido Lopez, Buenos Aires, Ediciones Banco Velox.
José Ignacio Garmendia: crónica en imágenes de la Guerra del Paraguay (2005): Buenos Aires, Fundación Universitaria Católica Argentina.

Pereira, Walter Luiz (2003): Óleo sobre tela, olhos para a história, memória e pintura histórica nas Exposições Gerais de Belas Artes do Brasil Império (1872 e 1879). Niterói (Dissertação de Mestrado, História, UFF).

Pereira, Walter (1999): "E fez-se a memória naval. A coleção de Edoardo Martino no Museu Histórico Nacional", Anais do Museu Histórico Nacional, Rio de Janeiro, vol. 31.

Pérez Vejo, Tomás (1996): Pintura de historia e identidad nacional en España, Tesis Doctoral, Universidad Complutense de Madrid.

Reyes Fragoso, Arturo (2003): Los Pinceles de la Historia III: la fabricacion del Estado (1864-1910) Del imperio de Maximiliano a las fiestas del Centenario (promocion de las artes y politica cultural de jefes de estado) México, Coedición con el Consejo Nacional para la Cultura y las Artes, el Instituto Nacional de Bellas Artes y el Museo Nacional de Arte.
Souza Silva, Joaquim Norberto de (1873): História da Conjuração Mineira: Estudos sobre as primeiras tentativas para a independência nacional, Rio de Janeiro.

Squeff, Letícia (2007): "Esquecida no fundo de um armário: a triste história da Coroação de D. Pedro II", en Christo, Maraliz de C. V. (org.), "Dossiê Pintura de História", Anais do Museu Histórico Nacional. Rio de Janeiro, MHN, v. 39.

Squeff, Letícia (2004): O Brasil nas letras de um pintor, Campinas, UNICAMP.

Taunay, Visconde de (1926): A campanha da Cordilheira - Diário do Exército, Ed. Cia Melhoramentos, São Paulo.

Tobler/Lopacher (1969): Un suizo en la Guerra del Paraguay. Asunción, Editorial del Centenário.

Vainfas, Ronaldo (2002): "Guerra do Paraguai", en Dicionário do Brasil Império, 1822-1889. Rio de Janeiro, Objetiva.

Varnhagen, Francisco A. de (2002): História das lutas contra os Holandeses no Brasil, desde 1624 até 1654. Rio de Janeiro, Biblioteca do Exército Editora (1. ${ }^{\text {a } e d i c ̧ a ̃ o, ~ a i n d a ~ n a ~ f o r m a ~ d e ~ u m ~}$ ensaio: 1871). 